
\title{
28 Research Square \\ Trade-Offs in German Wind Energy Expansion: Building Bridges Between Different Interests, Values and Priorities.
}

Sybille Reitz ( $\sim$ sybille.reitz@tum.de)

Technical University of Munich

Lauren Goshen

Technical University of Munich

Dörte Ohlhorst

Technical University of Munich

\section{Research Article}

Keywords: Energy Transition, Wind Energy Expansion, Trade-Off, Conflict Resolution, Societal sponsorship

Posted Date: December 29th, 2021

DOI: https://doi.org/10.21203/rs.3.rs-1173628/v1

License: (c) (i) This work is licensed under a Creative Commons Attribution 4.0 International License.

Read Full License 


\section{Abstract}

Background: In order to achieve climate targets, a transition to low-carbon energy production is necessary. However, conflicts between different interests, values and priorities, particularly at the community level, can constrain this transition. This paper aims to analyze lines of conflict and opportunities for building bridges between conflicting interests in the expansion of wind energy in Germany at the local level, in order to achieve successful implementation of wind energy projects.

Results: Our analysis of four cases of local-level wind energy projects in Germany shows that limited local options for action reinforce the need for local actors to maximize the benefits of energy transition projects. In addition to the conflict over scarce space, the lines of conflict at the local level run primarily along the dimensions of costs and benefits, winners and losers. Real or perceived procedural and distributive injustices have the potential to fuel resistance to wind energy projects in the selected cases. Wind energy projects were successfully implemented in the four selected cases despite the presence of local opposition.

Conclusions: The results show that, by integrating procedural and distributive justice and offering tailored solutions, community support for expansion of renewable energy projects can be enhanced. Further, the paper advances the concept of societal sponsorship, which is the willingness of members of a community to bear, or tolerate, decisions despite conflicting opinions. This concept is presented as an alternative to the concept of acceptance, which implies a positive, supportive attitude, and that protest should be avoided or overcome instead of recognized as a contribution to the debate. Societal sponsorship can be enhanced when procedural and distributive justice are adequately addressed.

\section{Background}

After the German Federal Constitutional Court decided that the German Climate Protection Act of 2019 was inadequate [19], the German federal government announced a plan to achieve carbon neutrality by 2045. This requires a faster expansion of renewable energies, and as a result the competition for space for energy infrastructure will intensify while local protest increases. This is exemplified by the industry survey carried out by the "Fachagentur Windenergie an Land" (Specialist Agency Onshore Wind Energy) together with the Federal Wind Energy Association [113]. According to the survey, lawsuits against 325 wind power plants in Germany with a capacity of 1,011 Megawatts (MW)[1] were pending in court in the second quarter of 2019, with the most common reasons for complaints being nature conservation and species protection. During the legal proceedings, which usually last several years, the affected wind turbines could neither be built nor operated.

The majority of citizens in Germany support the energy transition and are generally supportive of renewable energy systems $[2,20,40,41,60,127]$. At the same time, the energy transition is associated with various political challenges. One of the challenges lies in the multi-level system of German federalism: the German energy transition is jointly governed by the national (federal) and subnational 
(state) level. The subnational governments can complement national rules with their own laws and regulations [105]. But the implementation of the (increasingly) decentralized energy supply system lies primarily with local governments. Accordingly, the conflicts for space, especially related to wind energy deployment, largely have to be dealt with on the local level. In the context of the energy transition, municipalities' policy options range from strategic and planning activities (land-use planning, approval processes) to carrying out their own energy management activities [11]. Designation of wind energy areas and decisions about the locations of wind turbines by local governments is limited by state and regional planning laws and regional land-use designations which supersede local planning authority. As a result, while this varies across the German states, municipalities generally have little discretion over siting decisions governing wind turbines (see $7,78,79$ ). Further challenges in addition to the limited scope for decision-making at the municipal level include, for example, the conflicting goals between climate and environmental protection, biodiversity and land use, as well as social costs and benefits $[23,28,33,36$, $100,114,150]$. The classification and evaluation of these conflicts is often based on different $[85,86]$ personal normative beliefs and values with regard to the energy transition and can create a feeling of injustice and powerlessness among affected citizens - and can thus affect the acceptance of the energy transition by the public.

Despite extensive research on acceptance and aspects of energy justice $[27,30,39,67-69,84,86,88-90$, $97,132,133]$, there are still uncertainties regarding the question of whether and how a consensus between the conflicting interests and different values and normative beliefs can be found and whether compromises can be negotiated. The aim of this study is to contribute to the development of mechanisms, instruments and institutions that help to build bridges and to find compromises in order to work against the often-perceived unbalanced distribution of burdens or to prevent them from arising in the first place. The present study examines the question of how procedural and distributive justice in local wind energy projects can build bridges and initiate consensus building. In addition, this study takes a critical look at the prevailing understanding of acceptance in the literature.

\section{Acceptance and Societal Sponsorship}

In the academic literature, social acceptance is regarded as a central factor enabling successful implementation of infrastructure projects, including sustainable energy projects $[97,126,128]$. Acceptance is particularly relevant in the context of the expansion of wind energy $[26,85,153]$. However, Zuber and Krumm [153] characterize "acceptance" as a "difficult term" in the context of the energy transition due to the lack of a clear definition and the general understanding of acceptance as having a positive connotation. Acceptance is generally associated with words such as "acknowledge, consent, affirm, agree"; hence, a person who accepts something "provides a positive value judgement" [153]. Batel [9] and Colell [26] criticize that the understanding of acceptance that has so far prevailed in the scientific literature is insufficient (for a comprehensive discussion on this see, in particular, Colell [26]). Batel [9] argues, for example, that some theoretical proposals and concepts have contributed to the notion that the opposition to renewable energy transition is found on the local level. This criticism relates to the concept of Wüstenhagen et al. [151] in which community acceptance is separated from socio-political acceptance 
and these are analyzed as distinct domains [9]. Thereby, "socio-political acceptance is social acceptance on the broadest, most general level" while community acceptance is "acceptance of siting decisions and renewable energy projects by local stakeholders, particularly residents and local authorities" [151]. This separation between community members and the public is understood as an artificial separation of the "national and the local" [9]. Colell [26] criticizes that, in the context of community acceptance, protest is viewed as something to be avoided or overcome, "rather than acknowledged as a contribution (re)politicizing the debate of energy system change". Furthermore, the full range of attitudes of communities toward energy projects such as support, uncertainty, and apathy, are typically ignored under the acceptance framework [10].

Drawing on this criticism, and supported by the findings of the present case study, we put forward the broader concept of "societal sponsorship" as a central point of our analysis. We conceptualize societal sponsorship as a more active understanding of society, according to which society deals more consciously with the limitations, advantages and disadvantages of the energy transition. This concept recognizes that stakeholders who are affected by the energy transition are willing to tolerate decisions that are made on the basis of fair compromises and fair processes. In our study we use the concept of 'Energy Justice', which offers a suitable theoretical framework for assessing the question of whether the processes and results of energy policy and energy transition projects are just and fair, and in turn contribute to achieving societal sponsorship. The importance of questions of justice in the energy transition, especially the dimensions of procedural justice (fair participation in planning and decisionmaking processes) and distributive justice (fair distribution of costs and benefits) is recognized by various authors $[57,69,74,97,104,151]$. We argue that the chance of gaining societal sponsorship of wind energy projects is higher if distributive and procedural justice are present in the planning and implementation process of the project.

According to Jenkins et al. [67], the concept of energy justice encompasses three main aspects: "(a) where injustices emerge, (b) which affected sections of society are ignored, (c) which processes exist for their remediation..." [67]. A similar approach is taken in McCauley et al. [89], which describes energy justice as a "triumvirate of tenets", including the three tenets of procedural, distributive and recognitional justice [89]. For this purpose, it is also understood that (in)justices include those which are both real and perceived [67].

In order to analyze policies and systems under an energy justice framework, we follow the approach of Mundaca et al. [97], which identifies procedural and distributive justice as two main aspects of energy justice [97]. In this regard, procedural justice relates to decision making processes and is aimed at providing access to processes to all actors in a non-discriminatory manner. Indicators of procedural justice include transparency, access to information, recognition of unjust procedures, and lack of bias by decision makers. Particularly in the local context, information sharing, exchange of ideas, early inclusion in processes and ability to be heard are decisive factors for local acceptance. Distributive justice is related to the outcomes of the decision-making process, particularly the distribution of costs and benefits. In terms of wind energy projects, typical examples of perceived distributive injustices relate to the chosen 
location of wind power plants, the selection of the energy provider, ownership questions, income, and compensation measures [97]. These two main aspects of the energy justice framework, with the pertinent concepts and indicators, are depicted in Figure 1.

[1] Data as of second quarter of 2019.

\section{Methodology}

Through detailed analysis of four selected cases involving conflicts over wind energy projects, we identified mechanisms, processes, and actors that have contributed to negotiating compromises between differing interests, values and normative beliefs. These cases were analyzed under the energy justice framework (see Fig. 1) to evaluate how procedural and distributive (in)justice were addressed, and in turn, how this can explain the ultimately successful implementation of wind energy projects in each case.

In order to identify suitable cases for our study, we analyzed German newspapers, magazines, and journals in the Nexis Uni Database spanning a time frame from 2015 to 2020 . The contents of these sources were indexed according to various topics: environment and natural resources, labor and employment, society, social welfare and lifestyle, and energy and utilities and environmental industries. A limitation was that the Nexis Uni database does not include all German daily newspapers; widecirculation dailies such as the Frankfurter Allgemeine Zeitung and Süddeutsche Zeitung are excluded.

The next step was to specifically search for coverage of successfully implemented renewable energy projects. Details of these projects, including the type of renewable energy generation and existence of local protests, were further verified in pilot interviews. For this purpose, nine pilot interviews were conducted by telephone between November 2020 and January 2021. Interview partners were drawn from individuals named in the articles collected during the media research step, and from contact persons named by those individuals.

Subsequently, we narrowed the focus of our study to cases in which wind energy projects were successfully implemented, despite protests from the local community during the planning phase. In order to incorporate different regional contexts into our study (see Ostrom [106]), cases from four different regions of Germany were chosen: Brake in Lower Saxony, Uebigau-Wahrenbrück in Brandenburg, Kefenrod in Hesse, and Berg in Bavaria.

The qualitative analysis of these cases was performed by evaluating documents and interviewing local actors. From December 2020 to June 2021, 16 interviews were conducted with local actors who were either involved in the implementation of wind energy projects on site or observed them and were therefore able to describe the local processes and their characteristics. The interviews were semi-standardized and were conducted by telephone or videoconference. An interview guide was used to support the interviews, but it was not presented to the interviewees in advance. In order to protect the identity of the interviewees, the interviews in this report have been anonymized and assigned a reference number and corresponding interview date (see Table 1). To further prevent identification of interviewees in some situations, the 
reference number and date of the interview are replaced by the name of the city or town. Secondary sources used in the analysis include data from federal and state statistical offices, national and regional daily newspapers, official journals of public offices, and websites of municipalities, local media, ministries and companies.

Table 1: List of interviews, with function and/or job title of interviewees at the time of project implementation

\begin{tabular}{|c|c|}
\hline$\# 1-01.12 .2020$ - Nature protection & \#9 - 16.03.2021 - Forestry \\
\hline \#2 - 24.01.2021 - Municipal Administration & $\# 10$ - 16.03.2021 - Wind park developer \\
\hline \#3 - 23.02.2021 - Species Protection & $\# 11$ - 17.03.2021 - Wind park developer \\
\hline \#4 - 23.02.2021 - Municipal Administration & $\# 12$ - 25.03.2021 - Citizen \\
\hline \#5 - 23.02.2021 - Economic development & \#13 - 27.04.2021 - Municipal Administration \\
\hline$\# 6$ - 25.02.2021 - Forestry & \#14 - 26.05.2021 - Municipal Administration \\
\hline \#7 - 28.05.2021 - Wind park developer & $\# 15$ - 28.05.2021 - Regional planning office \\
\hline \#8 - 09.03.2021 - Municipal Administration & \#16 - 15.06.2021 - District-level official \\
\hline
\end{tabular}

To capture the range of contextual variables of the selected cases, we applied Ostrom's Institutional Analysis and Development framework (IAD). The IAD is a framework through which action situations and decision-making processes are analyzed, including the roles of participating actors, positions, power, and information. In applying the IAD, exogenous variables constituting the context, including the biophysical environment, community attributes, and existing rules, which influence the action and decision making processes are also defined $[94,107,108,119]$.

\section{Table 2: Definitions of IAD variables}




\begin{tabular}{|c|c|}
\hline Variable & Definition \\
\hline $\begin{array}{l}\text { Biophysical/material } \\
\text { conditions }\end{array}$ & $\begin{array}{l}\text { Physical, material environment, which influences possible actions taken in } \\
\text { action situations, for example, existing infrastructure. }\end{array}$ \\
\hline $\begin{array}{l}\text { Community } \\
\text { attributes }\end{array}$ & Socio-economic characteristics of the community. \\
\hline Rules & $\begin{array}{l}\text { Institutions, e.g., formal laws and regulations that enable or constrain } \\
\text { behavior of participants. }\end{array}$ \\
\hline Action situation & $\begin{array}{l}\text { Social interaction space, in which participants decide on actions on the basis } \\
\text { of the available information: how and to which outcomes do these actions } \\
\text { lead, and which costs and benefits are connected to these outcomes? }\end{array}$ \\
\hline Participants & $\begin{array}{l}\text { Individual actors or actor groups, e.g., governmental or non-governmental } \\
\text { bodies or firms. }\end{array}$ \\
\hline Interactions & Procedural aspects, i.e., interaction among participants in an action situation. \\
\hline Outcomes & $\begin{array}{l}\text { Results of interactions, which can be institutions, knowledge, or operational } \\
\text { outcomes, for example, implementation of new technologies. }\end{array}$ \\
\hline Evaluative criteria & $\begin{array}{l}\text { Criteria that are used to assess interactions and outcomes, e.g., sustainability, } \\
\text { distributive equity, economic efficiency. }\end{array}$ \\
\hline
\end{tabular}

Source: Adapted from Milchram et al. [94].

While we do not apply all of the variables of the IAD (see Table 2) systematically in our case analysis, we do draw upon several aspects of this framework. Hence, in the first step of our case analysis, we identified biophysical conditions forming the context of our cases and we consulted regional databases and official statistics to determine community attributes (size, location, number of inhabitants, sociodemographic and economic factors). In order to describe the respective action situations in each case, interviewees were asked about the origins of the local wind energy projects, with a focus on the location, procedure, project sponsor, costs and benefits. Drivers of action (e.g., climate change, nuclear phase-out, coal phase-out, revenues) were also investigated during interviews. After asking interviewees about their involvement in the projects and their attitudes toward the energy transition to capture their points of view, inquiry was made regarding participation opportunities, decision making and intervention options, and communication and information offerings $[107,108]$. Additionally, interviewees were asked about their experiences and opinions regarding mechanisms and instruments suitable to build bridges between conflicting actors or goals, to find compromises, or to resolve or avoid conflicts altogether.

\section{Results}

The cases analyzed in this study have different biophysical conditions and properties that influence the action situation on site, as well as interactions and decisions of the actors. These factors are shown in Table 3 below. For each of the four selected municipalities, the project genesis and local conflicts are described in this section, and procedural and distributive justice is analyzed. 
Table 3: Local characteristics

\begin{tabular}{|c|c|c|c|c|}
\hline Municipality & Berg, Bavaria & $\begin{array}{l}\text { Brake, Lower } \\
\text { Saxony }\end{array}$ & $\begin{array}{l}\text { Kefenrod, } \\
\text { Hesse }\end{array}$ & $\begin{array}{l}\text { Uebigau- } \\
\text { Wahrenbrück, } \\
\text { Brandenburg }\end{array}$ \\
\hline \multicolumn{5}{|l|}{ Characteristics } \\
\hline District & $\begin{array}{l}\text { Starnberg; located } \\
\text { at Lake Starnberg }\end{array}$ & $\begin{array}{l}\text { Wesermarsch; } \\
\text { seaport; located at } \\
\text { the western shore } \\
\text { of the Weser River }\end{array}$ & $\begin{array}{l}\text { Wetterau; } \\
\text { located in the } \\
\text { Darmstadt } \\
\text { region }\end{array}$ & $\begin{array}{l}\text { Elbe-Elster; } \\
\text { situated in the } \\
\text { local authority } \\
\text { association } \\
\text { Liebenwerda }\end{array}$ \\
\hline \multirow[t]{2}{*}{ Area } & 15 villages; & 11 city districts; & Five villages, & 20 city districts, \\
\hline & $\begin{array}{l}36.63 \mathrm{~km}^{2} \text {; mainly } \\
\text { forest and forest } \\
\text { areas. }\end{array}$ & $\begin{array}{l}38.30 \mathrm{~km}^{2} ; \\
\text { majority } \\
\text { agricultural use, } \\
\text { settlement- and } \\
\text { traffic areas. }\end{array}$ & $\begin{array}{l}30.67 \mathrm{~km}^{2} \text {; } \\
\text { mainly areas } \\
\text { for } \\
\text { agricultural } \\
\text { use. }\end{array}$ & $\begin{array}{l}135.61 \mathrm{~km}^{2} \\
\text { mainly areas for } \\
\text { agricultural use. }\end{array}$ \\
\hline Residents (2019) & 8,301 & 14,860 & 2,733 & 5,306 \\
\hline $\begin{array}{l}\text { Population } \\
\text { Density } \\
\text { (inhabitants } / \mathrm{km}^{2} \text { ), } \\
\text { average } 2019\end{array}$ & 226.6 & $\begin{array}{l}388 \\
\text { (high population } \\
\text { density }{ }^{[2]} \text { ) }\end{array}$ & $\begin{array}{l}90 \\
\text { (sparsely } \\
\text { populated) }\end{array}$ & $\begin{array}{l}38.39 \\
\text { (very sparsely } \\
\text { populated, rural) }\end{array}$ \\
\hline $\begin{array}{l}\text { Average annual } \\
\text { district income } \\
2018 \text { in } \\
\text { euros/capita }^{[3]}\end{array}$ & $\begin{array}{l}\text { Starnberg: } 35,356 \\
\text { euros one of the } \\
\text { highest income } \\
\text { districts in } \\
\text { Germany. }\end{array}$ & $\begin{array}{l}\text { Wesermarsch: } \\
21,936 \text { euros just } \\
\text { below the national } \\
\text { average income. }\end{array}$ & $\begin{array}{l}\text { Wetterau: } \\
24,647 \text { euros } \\
\text { above } \\
\text { German } \\
\text { national } \\
\text { average. }\end{array}$ & $\begin{array}{l}\text { Elbe-Elster: } \\
19,046 \text { euros well } \\
\text { below German } \\
\text { national average. }\end{array}$ \\
\hline
\end{tabular}

Sources: $[45,47,115-117,134]$

\section{Berg municipality, Bavaria}

Berg is a wealthy community in the Starnberg district in Bavaria and is located on the hilly, eastern shore of Lake Starnberg. Berg is a part of the greater Munich area. In Berg climate protection or renewable energies initially did not play a particular role; the municipality decided in 2009 to support a several yearold energy transition initiative of the district of Starnberg to supply the district with renewable energies by 2035 [44]. Interviewees described a positive attitude toward the energy transition and the expansion of renewable energies, including wind energy. Their main motivation driving the introduction of wind energy was above all climate change, but Germany's exit from nuclear energy also played a role. However, their positive attitude does not come without reservations, and interviewees called for other technologies such as photovoltaics, biogas or biological waste to also be included in the energy mix. Additionally, the perceived lack of attention to issues of energy efficiency and energy saving has made the energy transition incoherent, according to interviewees. 
In the municipality of Berg, local authorities established "Bürgerwind Berg" (Community Wind Berg), a private limited liability company, that started operating four wind turbines in 2015. The wind turbines are located between Berg and the community of Neufahrn, which is located within the neighboring municipality of Schaftlärn ${ }^{[4]}[22,42,44]$. The development of the turbines commenced with a resolution of the Berg municipal council in 2010 to designate concentration zones for wind power plants. These plans resulted from the reaction of the community to the plans of a Berg business person who had intended to build further wind turbines in addition to one he already privately operated [91]. With their proactive approach, the local authorities wanted to assert municipal decision-making authority and to ensure that the interests of the local citizens were taken into account when searching for the final location and designing the project [6, 46; Interviews \#1 vom 24.01.2021, \#12 vom 27.04.2021, 73]; [interviews \#1 on 24.01.2021, \#12 on 27.04.2021].

The Starnberg District Office had designated the forest area known as the "Wadlhauser Gräben" as the location for the Berg wind turbines [interview \#9 on 16.03.21]; [4, 7]. The municipality then signed a location security agreement with the Bavarian State Forests, which support municipalities [12] under the condition that the local population is in favor of the project and that a municipal council resolution exists [interview \#9 on 16.03.21; 24]. In this regard, Berg's municipal council resolution was adopted in March 2012 [98]. Although up to seven wind turbines would have been possible at the selected location [92], only four wind turbines were approved out of consideration for the local population $[43,131]$.

Various factors were particularly important with respect to implementing the wind energy project in Berg: a) the municipality was the initiator of the project; b) maximum economic efficiency of the project; $c$ ) it needed to be a community energy project, and d) equal footing between the municipality of Berg and the project developer [interviews \#1 on 24.01.21; \# 11 on 17.03.21]. For the latter reason, an originally planned collaboration with Stadtwerke München (the City of Munich's municipal utilities company) was not pursued, but instead a planning office was engaged [8, 22]; [interview Berg].

Citizens expressed their resistance to the wind turbines in Berg through numerous statements, an open letter and establishment of two citizens' initiatives opposing the wind turbines.

"I must have received around 250 letters from opponents. Among those, 200 argued against wind energy because of nature conservation. Some of them were at least honest to acknowledge their fear of the depreciation of their property as a reason for the opposition to wind energy. (...) Otherwise, the personal exchange was rather unpleasant, there were threats, angry emails, posters, demonstrations in front of the forestry office. You also got threatening calls that the Prime Minister would soon contact the Forestry Office and that the wind park would then be prevented" (interview Berg).

Opponents were concerned with the preservation of the forest, insight into the planning process, and nature and environmental protection [92, 141], and the citizen initiative "Verein zum Schutz der Wadlhauser Gräben“ (Association to Protect the Wadlhauser Gräben) aimed to prevent the wind turbines 
in Berg [62]. The citizens of the neighboring communities of Berg and Schäftlarn banded together to protest and created a poster campaign against the initiative of the then-mayor of Berg.

Individual members of the municipal council in Berg were also critical of a wind park [3], and the municipal council of Schäftlarn decided to take legal action against it [93]. Schäftlarn's main concern was a fair distribution of disadvantages attributable to the wind park [61]. Opposition to the wind park escalated to the point of death threats against the mayor of Berg [38]; [interview Berg].

\section{Procedural justice: information, consultation, decision}

After designating concentration areas for wind parks, Berg began the planning process and hired a planning office as a service provider, in order to assert its decision-making authority over the project [interview \#2 of 24.01.21]. For the citizens of Berg, a decision about whether the wind park would be implemented was not up for debate. The decision to set up a wind park in Berg was viewed as a preventive measure in order to avoid what was perceived to be imminent "uncontrolled growth" by private investors. Berg's activities were supported by the Starnberg District Office and the Bavarian State Forests (interviews \#11 of 17.03.21, \#9 of 16.03.21).

Public participation was a component of the planning process in Berg. Regionally, there is a goal to involve citizens in larger projects very early on [interview \# 5 of 23.02.21]. For example, the Starnberg District involved the municipalities and their citizens in developing a land-use plan for wind energy [7]; [interview \# 16 of 15.06.21]. Neighboring Schäftlarn was informed about the plans early on but was not consulted about the location. Actors involved in the process viewed the mandatory notification of the planning process as fulfilling the need to involve all affected actors [140]; [interview \#13 of 27.04.21]. The planned location for the wind turbines was situated directly at the border of the municipality of Schäftlarn [interview \#13 of 27.04.21] and was therefore closer to Schäftlarn than to the residential area in Berg [interview \#9 of 16.03.21]. For the Bavarian State Forests, a condition for establishing wind turbines in the state forest area was not to build these against the will of the local population [24]. This requirement and its validity for neighboring communities was confirmed to the community of Schäftlarn after it sought a conversation with the Bavarian State Forests. However, it was later argued that the interests of the neighboring communities were already addressed by their ability to participate in the district-level land use planning procedure [interview \#13 of 27.04.21]. In this regard, Schäftlarn was not characterized as the relevant local population in the same sense as the Berg community, and Schäftlarn's agreement was not essential to the State Forests' decision to move forward with implementation [interview \# 9 of 16.03.21]. The introduction of the wind park project in Berg was accompanied by public and non-public meetings, festive activities, a groundbreaking ceremony, a beer social event, and communication measures. Several information events and a panel discussion were held. In addition, there were municipal council meetings [92, 131]; [interviews \#9 of 16.03.21, \#11 of 17.03.21], in which citizens of the local community and the neighboring communities could participate. The municipal council meetings were key to the decision-making process, and opposition and 
critical questions were heard in these meetings [interview \#11 of 17.03.21]. However, from Schäftlarn's point of view, the community's concerns were not adequately addressed.

"You will not be able to resolve personal sensitivities. But people affected by the project were not heard. On the contrary. Yet, those affected should feel that their concerns are being taken seriously. Certainly, this is beyond legal possibilities. But taking people's concerns seriously is important. In addition, it should be justified why something is done a certain way and not differently" [interview \#13 of 27.04.2021].

Official meetings with the mayor were described as further means of information and communication [interview \#11 of 17.03.21]. In addition, the intensive personal support of critical citizens by the mayor and the project developer was considered an important bridging element for the "silent majority" [interview \#11 of 17.03.21]. ${ }^{[5]}$ The construction phase was documented in detail on the Berg community website [42], and an energy monitor was made available through which the energy mix, the status of the energy supply by the municipality's own wind park and the development of the share of renewable energies could be observed [13].

\section{Distributive justice: cost/benefits}

Despite the intention of the municipal representatives to derive the greatest possible benefit from the wind park in Berg by securing their decision-making authority, citizens primarily expected disadvantages. They feared high costs, negative impacts on health (subsonic noise, shadows, red light), impacts on nature and species protection [interviews \#11 of 17.03.21, \#9 of 16.03.21] and economic disadvantages (to property owners, tourism and leisure business) [interviews \#5 of 23.02.21, \#9 of 16.03 .21 ; \#11 v. 17.03.21]. However, fears about lost property values and reduced tourist activity did not materialize; rather, real estate prices rose and overnight stays in Berg increased [interview \#5 of 23.02.21].

Health concerns were addressed with technical noise control inspection certificates. Measuring devices were installed to minimize the negative impact caused by shadows and red light [interview \#11 of 17.03.21]. The interference with nature was balanced by compensatory measures (payments by the operator to an environmental fund, reforestation) [interview \#2 of 24.01.21]. Additionally, although the forest area of the "Wadlhauser Gräben" is a mixed forest, the use of the area for wind energy was classified by a local expert from a nature protection organization as harmless from a nature conservation point of view [7]; [interview \#9 of 16.03.21].

In order to increase local economic benefit, the municipality decided to operate the wind turbines itself

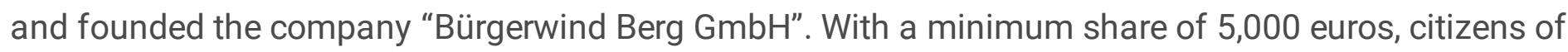
Berg and neighboring communities were able to invest directly in the wind park. First and foremost, local investors were preferred in the allocation of shares $[43,55,63,131]$. The municipality of Berg also participated, so that - after loan repayment - the municipality and its residents would fully benefit from the return on investment. Despite the successful participation model, not all actors are convinced that financial participation increases acceptance of wind turbines: 
"The possibility of financial participation for citizens is nice. (...) However, from my point of view, this does not solve the local conflict. At least not in our region. (...) In principle, I don't believe that people who have wind turbines in front of their noses can be satisfied. Especially not in Munich, there are lots of rich people living there. And people live there because they want and can enjoy the high quality of life. I don't think that you can convince these people by involving them in the process or providing more information. (...) People still think that electricity comes from the socket. And it just stops where your own contribution begins. It's okay if there are wind turbines in Saxony-Anhalt and people like to participate financially. But please not here" [interview \#9 of 16.03.21].

Due to the ongoing conflict over the wind park, citizens of neighboring Schäftlarn did not take advantage of the offer of financial participation [interview \#13 of 27.04.21].

According to an interviewee, the conflict with Schäftlarn could have been eased through a compromise on the location of the wind park:

"Ok, it was already a compromise that only four of the eight possible wind turbines were installed. However, all four have been placed on the border with Schäftlarn. So, they are in the north of Berg, but in the southwest of Schäftlarn, thus in front of the terraces of the residents of Schäftlarn. In order to achieve a fairer distribution, the Schäftlarn residents had proposed to move two of these four wind turbines to another location in the south of Berg, but this was rejected. That left a bad taste. There are people who say that the Berg wind turbines can be seen from everywhere, except from Berg" [interview \#13 of 27.04.21]; [see also 61; 140].

The interviewee suspected that financial compensation for neighboring communities could have reduced possible location problems:

"So, not only the municipality within which the wind turbines are located is compensated, but those municipalities within a radius of 2.5 kilometers. The advantage is that the municipalities have to share their income when they put the wind turbines on the border to the neighboring municipality. In order to keep all the income, they would then have to distance the wind turbines from their neighbors" [interview \#13 of 27.04.2021].

Some interviewees in Berg expressed doubts about the coherence of the energy transition. Out of fairness, they expected transparency about the conflicting goals of the energy transition and openness about the advantages and disadvantages. The impacts, in particular on people and species protection, should be presented and justified in the context of an overall concept: why was which solution pursued (for example, wind turbines in areas with low winds) and which alternative measures were taken? According to interviewees, decisions should be based on an overall consensus, with Bavaria also having to make compromises instead of generally refusing to use wind energy ${ }^{[6]}$ [interview \#13 of 27.04.21].

\section{City of Brake, Lower Saxony}


The City of Brake is engaged with the energy transition as a participant in the project "HyLand - Hydrogen Regions in Germany" and through its goal to make its port CO2-free [16]. The positive attitude of municipal decision-makers towards the energy transition is driven primarily by climate change.

Since 2002, five wind turbines have been in operation in the "Hammelwarder Moor" area of Brake [65]. To determine additional potential for wind energy, Brake developed a location concept, which was unanimously approved by the city council in March $2014[49,118]$. Two locations were identified in Brake as suitable for additional wind turbines: an area in the northwest of the existing "Hammelwarder Moor" wind park and the "Golzwarderwurp" area on the northwestern city limits of Brake. The selected areas are privately owned agricultural areas, as the city does not own any land itself. As a result of the designation of wind development areas, two wind project developers approached the city with the intention to build wind turbines [interview \#14 of 26.05.21]. In November 2015 and February 2016, the city announced plans to create a project-related municipal building and development plan for both wind park areas [79, 80] and approved the corresponding land-use plans [120]. Both project developers submitted a concept to the city council for approval [see for example 53]. The city signed urban development contracts with the developers, in which the height of the wind turbines as well as certain compensation measures were defined [interview \#13 of 26.05.21]. Of the three wind turbines planned in the Hammelwarder Moor, two turbines went into operation in 2017 and the third in $2018[3,124]$. The wind park with six wind turbines built in Golzwarderwurp has been in operation since 2017 [64].

During planning of the wind parks, two citizens' initiatives were formed against them $[59,66]$. The initiatives were opposed to lifting the priority for green spaces, but also anchored arguments against the wind parks in historical monument protection and the destruction of cultural landscape. In the Hammelwarder Moor in particular, there were concerns that the stability of buildings would be endangered by lowering of the groundwater level necessary for construction and the moor-like ground [50]. But there were also concerns about adverse effects on health from shadows, subsonic noise, construction noise and truck traffic [129, 130]; [interview \#13 of 26.05.21]. The protesting residents felt ignored by the City of Brake and above all demanded transparency $[58,59,144]$. The citizen initiatives teamed up and launched two petitions, but both did not attract the necessary number of supporters to move forward $[15,37]$. The proposal to approve the implementation agreement for the Golzwarderwurp wind park was adopted by the city council with one vote against and one abstention [122]. The construction work in the Hammelwarder Moor was temporarily stopped due to a lawsuit by three residents [123]. One of these lawsuits was still pending in court in November 2020 [125].

\section{Procedural justice: information, consultation, decision}

The processes for the construction of wind parks in Brake started with the city's initiation of the expansion of an existing wind park by carrying out a wind energy potential analysis. Since the wind turbines were to be placed on privately-owned plots, the city's decision-making power was limited to the design of the land use plan and the conditions for implementation by the developer. One interviewee pointed out that the city had the opportunity to control the project via the development plan and urban 
development contracts, which is the option that was used [interview \#14 of 26.05.2021]. During the implementation of wind energy plans, the mayor and city council encouraged the involvement and consultation of residents [54]. Accordingly, public participation, in the form of information events, was initiated at an early stage for both wind parks as part of the preparation of the project-related municipal development plans $[79,80,102,103]$. For the residents, however, a decision on whether to build wind parks was not put up for debate. The majority of the municipal actors involved had a positive view of wind energy and pushed forward with its expansion. The city imposed conditions on the developer with regard to the height of the wind turbines and the distance to residential areas. After a discussion with residents, it was communicated to the project sponsors that the maximum height of the wind turbines would be limited to 175 meters and the wind turbines would have to be at least 500 meters away from the nearest residential area. In this way, the city reacted to citizens' concerns about noise and depressing effects caused by the wind turbines [51, 52]; [interview \#14 of 26.05.20]. Although the developer would have had the right to build 200-meter-high wind turbines, one interviewee justified the height and distance requirements as follows:

"I am supposed to be there for the residents and I have to keep harm away from them. If a company presents demands to me, then they can just go away. For example, a company approached the city and wanted to build higher wind turbines. I declined, because it has been agreed with the residents that the maximum allowed height is $175 \mathrm{~m}$. (...) The company also absolutely wanted to prevent the city from drawing up a development plan. But I cannot consider this, either there is a municipal development plan or an urban development contract. Sure, the company can sue me. But please, should they, we are waiting this out and the project will only be delayed. I have options (...), and then they have no chance" [interview \#14 of 26.05.21].

The city requested that the developer "takes the citizens with them" in the implementation of the project and engage in public participation. When one of the developers seemed to hesitate, the city exerted pressure to push for participation measures [interview \#14 of 26.05.21].

The city jointly organized public events with the project sponsors (a large information event on the Hammelwarder Moor, three public events at the Golzwarderwurp wind park) [50, 129]; [interview \#14 v. 26.05.21]. A site inspection was carried out at the Golzwarderwurp site with a newly founded citizens' initiative, during which concerned citizens were able to exchange ideas with the mayor and representatives of the city council. This provided an opportunity to address an information deficit that had led to incorrect assumptions about the wind park [58]. Furthermore, the city and project sponsor offered a hotline and regular consultation hours for citizens to discuss complaints and problems. In addition to the formal information offered, there were informal events, such as a barbecue with affected residents [interview \#14 of 26.05.21].

Distributive justice: costs / benefits

For the political actors in Brake, the increase in local added value was an important argument in favor of introducing wind energy.

Page $14 / 44$ 
"Financially, Brake is not a bed of roses. However, the financial situation has improved since 2015. At least there were no more negative budgets. The trade tax from wind energy of 150,000-200,000 euros is negligible, but residents already notice the better financial situation“ [interview \#14 of 26.05.21]; [see also 129].

One interviewee stated that it is difficult to bring this complex topic closer to residents and to explain goals such as economic benefit. However, acceptance would increase if such a project provided substantial added value for the municipality, and not just for wind park operators and farmers on whose land wind turbines are built. More general financial participation opportunities were also addressed by an interviewee:

"It would be good to develop participation models. There is an energy cooperative nearby. You can invest and get 4-5 percent interest. That's great these days. But if you ask people to invest at least 20,000 euros, then nobody can do that. Small amounts must be possible, such as 200 euros" [interview \#14 of 26.05.2021].

Financial participation in this form was not employed in Brake, but Brake was able to incur economic benefits for the city through agreements aimed at trade tax payments. One project sponsor was obliged to establish a local company. A contract was signed with the mayor of the municipality in which the company is originally located, regarding the distribution of trade tax income. The other project sponsor agreed to waive special tax depreciation (known as "Sonder-AFA") [101]; [interview \#14 of 26.05.21]. However, the demand for financial compensation for local residents of Brake, to address the disadvantages caused by the wind turbines, was refused.

"In order to pacify the conflict in the 'Hammelwarder Moor', [the resident and Green Party politician; author's note] Meyer-Ott proposed a new path - and failed. In order to make residents into winners of the wind park, he wanted to provide all homeowners within a radius of 1000 meters with a share in the revenues of the feed-in tariff. Owners of the land on which the wind turbines are built would have had to give up some of their share of revenues - and refused. Some of them are said to have prevented residents from buying shares in one of the wind turbines and thus becoming winners of the project on their own doorstep" [66].

Instead, the 16 landowner families have founded an association (known as a Förderverein) which, in consultation with the project sponsor, makes funds available for socially beneficial purposes in the region [121; 124]; [interview \#14 of 26.05.21].

One of the two project sponsors responded to the concerns of two residents that the stability of their houses could be damaged due to possible lowering of the groundwater and the swamp-like ground near the wind park. The project sponsor offered free building assessments before and after the completion of the work to document and compensate for possible damage to the houses [50, 101, 129]; [interview \#14 of 26.05.21]. Another compromise was found with citizens who complained about shadows cast by the rotors. Although the calculations indicated that shadows were in the normal range, the project sponsor 
offered to pay for window blinds for the residents [101]; [interview \#14 of 26.05.21]. Furthermore, an offer was made to buy residents' houses if they felt that their quality of life was permanently impaired. One resident has reportedly taken advantage of this offer [101]; [interview \#14 of 26.05.21). Finally, compensation for the loss of market value was offered by IFE Eriksen, the owner of the Golzwarderwurp wind park. Residents were given the opportunity to have their house values appraised by an independent consultant, and IFE would pay the difference for houses sold within five years at below market value [101]. Through these creative problem-solving approaches tailored to individual needs, citizens are more likely to be motivated to tolerate the wind energy project, which supports the concept of societal sponsorship.

For the members of the citizens' initiatives in Brake, regional justice played a role in their opposition to the wind parks, in addition to nature and environmental protection. A citizen from Brake pointed out that the citizens' initiative formed in opposition to the Golzwarderwurp wind park was not an opponent of wind turbines but did not want to participate in the "wind madness" in the Wesermarsch District. "We have already more than achieved the energy target, why more wind turbines?" asked one citizen [59]. Despite the general support for wind energy from municipal actors, the coherence of the energy transition with regard to choice of technology was also discussed in Brake. The central question was whether wind energy was "the ultimate wisdom", and whether innovative ideas with less negative effect on citizens had a chance, or whether the lobby interests of energy producers had already created a technological path dependency [interview \#14 of 26.05.21].

\section{Kefenrod municipality, Hesse}

In the municipality of Kefenrod, motivation to support the expansion of renewable energies is primarily driven by climate change, but the national exit from coal and nuclear power generation also plays a role. All interviewees were favorable toward the energy transition and the expansion of renewable energies, but the increasing consumption of resources by society, issues such as the unresolved questions of dismantling wind turbines, and the perceived incoherence of the overall concept for the energy supply system were viewed critically.

Currently, there are four wind turbines in Kefenrod. The planning process for Kefenrod's wind park began in 2011, it was approved by the Darmstadt Regional Council in February 2013 [35], and the turbines have been in operation since April $2014[5,109]$. The plans were secured by a municipal development contract and a contract between the project sponsor and the municipality.

The development contracts for the wind park ended a long-term debate around wind energy in Kefenrod [35], with the municipality responding to increased interest in locations for wind turbines. From the point of view of community representatives, it was problematic that many companies had concluded preliminary contracts with property owners without first consulting the community [87], which led to an "unpleasant gold rush mood". This situation was improved by the decision to build wind turbines only on municipally-owned land [112]; [interview \#6 of 25.02.21, \#8 of 09.03.21]. It was important for the municipality to retain planning sovereignty over the process [112]; [interviews \#6 of 25.02.21, \#8 of 
09.03.21]. Exercising its authority, the municipality reduced the originally planned wind energy development area from 250 to 55 hectares and added a development freeze to the municipal building development plan in order to prevent "uncontrolled construction" [87]; [interview \#8 of 09.03.21]. The final location of the wind park was selected after an on-site inspection with the project sponsor, community representatives, foresters and nature conservationists [112]; [interview \#6 of 25.02.21]. The decision was taken to build the wind turbines in a forested area that was damaged by storms[71]; [interviews \#1 of 01.12 .20 , \#6 of 25.02.21, \#8 of 09.03.21]. The project sponsor is a subsidiary of the local electricity supplier. The perception of this developer as a "local company" significantly contributed to trust and acceptance in the community [135; 111, 112]; [interview \#8 v. 09.03.21].

Conflict in Kefenrod around wind energy arose from the general rejection by the municipality, which had "permanently defended itself against wind energy" [87] and had left potential project sponsors stranded. Reasons for rejection of wind energy cited by residents of Kefenrod included: changes in the landscape, unjust burden sharing, the destruction of nature, the red blinking of the wind turbines lights at night, and proximity to residential developments. One resident is quoted as saying, "Basically this is a shame. We are selling our beautiful landscape. 55 hectares of priority area is the lesser evil compared to 250 hectares, but it is an evil" [48, 87]. In the run-up to local elections in March 2011, the expansion of wind energy was also discussed in the local media. Above all, the top candidate of the Free Democratic Party refused to approve further wind turbines in densely populated areas and criticized the "pollution of the landscape". The Free Voters (Freie Wähler) were also cautious, and the Christian Democratic Union formulated its position on wind energy as "yes, with restrictions on further wind turbines" [142]. Hence there was lack of support for - and even outright opposition to - the wind park in Kefenrod from some residents and local politicians.

Procedural justice: information, consultation, decision

The top priority for the municipality was retaining its autonomy in determining the use of its municipal lands. Representatives of the municipality feared that their decision-making authority would be restricted by the development of a new regional-level special land-use plan for renewable energies.

"We were, so to speak, forced to intervene by creating priority areas in order to keep the process in our own hands and not be controlled from outside. (...) They imposed a plan on us that we didn't want. We would have had to provide for the use of private property for wind energy deployment and we didn't want that. That would cause trouble [interview \#8 of 09.03.2021].

Another factor that Kefenrod residents viewed as a threat to their decision-making authority was that a non-local project planning office, which had been active in Kefenrod for many years, had planned wind turbines directly with private property owners and bypassed the municipality.

In Kefenrod the conclusion was reached that wind energy could not be prevented permanently, but "uncontrolled growth" should be avoided [interview \#8 of 09.03.21]. It was considered a compromise that the mayor at the time initiated and closely monitored the development of wind turbines, in order to have 
maximum influence on the project development and to ensure maximum benefit for the municipality [interview \#10 of 16.03.21]. According to one interviewee, there was a sense that events were quickly unfolding. Due to this dynamic, residents got the feeling that wind energy was unavoidable; thus, the municipality needed to take the initiative to maintain as much control as possible and to extract benefits for its citizens [interview \#8 of 09.03.21].

It was important for local decision-makers to determine a project sponsor who "then at least does what they [the community, editor's note] want" [interview \#10 of 16.03.21]. The community approached its regional energy and water supplier [interview \#3 of 23.02.21]:

"In this case, there is a local company involved, which is also a regional electricity supplier. They will not decide or do anything against the local residents. Because they can't afford to scare away thousands of their customers. They know the local circumstances" [interview \#8 of 09.03.2021].

An interviewee who successfully campaigned against the construction of wind turbines in a neighboring community confirmed the importance of trust in the project sponsor.

"They all [community representatives; author's note] have obstructed ABO Wind. There was general consensus on that. We already knew ABO Wind from the project in Ranstadt. We knew how to do it. We collected ammunition very early on. We knew how ABO Wind operates, we gathered information and we assessed it correctly. There were important questions that occurred locally that were not even addressed but were simply swept under the table. Of course, there were citizens' events, but they simply concealed problems" [interview Kefenrod].

The short decision-making channels to the project sponsor were important to the municipal actors. Many things could be decided via "informal channels". It was also important to the municipality that the company was available for on-site visits, which from its point of view led to the selection of the best site and a balance of interests [interviews \#6 of 25.02.21, \#8 of 09.03.21]. One interviewee took issue with decision-making processes concerning the locations of wind energy developments, criticizing that project planners often fail to visit the site along with the local authorities when deciding locations, which can lead to problems [interview \#6, 25.02.21]. Another interviewee confirmed the advantages of finding a location in cooperation with the municipality:

"We used to offer very customized solutions for the communities. Today, that doesn't exist anymore. The regional councils develop areas according to very rigid criteria, traffic routes and wind frequency. (...) But the customization is important. People sit on the terrace, most of which face the south. And when I plan wind turbines there, I can be sure that I have opponents" [interview \#10 of 16.03.21].

The local nature conservation association (NABU-Gruppe Bindsachsen) was also involved early in the process [interview \# 6 of 25.02.21] and confirmed the professional and qualified procedure of the project sponsor. The association additionally considered the location in the forest to be harmless [110]. As a result, the association was committed to the construction of the wind turbines and engaged in informing 
critical citizens at numerous events [interview \#1 of 01.12.20]. Citizens were also able to obtain information and exchange ideas during an event organized by the municipality and the project sponsor, through the community paper, through discussion evenings with interest groups and in bilateral talks [interviews \#3 of 23.02.21, \#6 of 25.02.21, \# 8 of 09.03 .21 , \#10 of 16.03.2]). After the wind park opened, citizens were able to attend an open house [72].

Distributive justice: costs and benefits

Benefits to the local economy played a central role in Kefenrod, and generating revenue for the municipality was a main argument in favor of wind turbines [111, 135]; [interviews \#6 of 25.02.21; \#8 of 09.03.21; \#10 of 16.03.21; \#12 of 25.03.21]. These benefits helped to gain support for the project and catered to the concept of societal sponsorship.

"Another important factor (...) was the chance, in our rural areas which are often financially weak, to have the opportunity (...) to earn money from business taxes. The social factor also played a role" [interview \#8 of 09.03.2021].

For this reason, the decentralization of the energy supply was seen as an advantage and was perceived as fair with regard to local value creation [interview \#10 of 16.03.21]. "Financial participation for all" and finances for the common good were in the foreground.

"Overall, how it went was positive. OVAG as the project developer and HessenEnergie kept their promises. Only the trade tax revenues did not come as OVAG had described. And when a community does not have any lease income, then that is stupid" [interview \#8 of 09.03.2021].

With the goal of improving the tax revenues of the communities, one interviewee suggested improvement of depreciation options for wind turbines, such that they would break even faster and thus municipalities would receive trade tax payments sooner [interview \#10 of 16.03.21]. Compensation of neighboring communities was also put forward as an equitable compromise [interview \#8 of 09.03.2021]. One interviewee found lacking a balancing of costs and benefits [interview \#3 of 23.02.21]. Another faulted missing links to other energy or infrastructure projects:

"The implementation and compromises, those stand and fall locally on the grounds of attractiveness. What is the benefit to me? There are already things that lawmakers can make more attractive. For every intervention in nature, compensatory measures have to be taken. That could be combined with further subsidies and other projects, for example, buying a biogas plant for the farmers alongside the wind turbine" [interview \#8 of 09.03.2021].

Compensatory measures in the project developer's offer included: security payments for turbine dismantling, compensation land, biotopes, automatic shutoff, and a feeding station for red kites [interviews \#1 of 01.12 .20 , \#6 of 25.02.21]. However, there was limited confidence in the long-term monitoring of compensatory measures. 
Certification programs, such as green or fair energy labels, were also discussed. One interviewee found a label for the evaluation of project developers helpful, but another preferred a local energy provider which would not be expected to act against the interests of local clients [interviews \#3 of 23.02.21, \#8 of 09.03.21]. A further interviewee expressed interest in such labels, but ultimately preferred energy cooperatives as wind energy operators, due to ease of compromises [interview \#10 of 16.03.21].

In Kefenrod, in addition to procedural and distributive justice, overriding issues with the energy transition were also discussed. For example, it was pointed out that conflicting objectives (e.g., overexploitation of land) should have been addressed and conditions such as dismantling or recycling should have been clarified, because these topics offered points of attack for opponents of wind energy [interview \#8 of 09.03.21]. The economic model of the energy transition also needed clear explanation [interview \#12 of 25.03.21]. An interviewee stated:

"It is already necessary to think about the energy transition. But the way there is questionable. On the way to the energy transition, too much attention is paid to the interests of different lobbyists and interests of various sectors. I see that critically" [interview \#3, 23.02.21].

An interviewee opined that energy saving and energy efficiency should be given higher priority, as an alternative in case wind turbines do not receive local majority support [interview \#10 of 16.03.21]. Interviewees expressed diverging opinions on balancing between nature and species protection and the needs of people, against the background of the energy transition [interviews \#1 of 01.12 .20 , \#3 of 23.02.21, \#8 of 09.03.21, \#10 of 16.03.21].

\section{City of Uebigau-Wahrenbrück, Brandenburg}

In the City of Uebigau-Wahrenbrück, the motivation behind support for the expansion of renewable energy is driven by climate change as well as the region's experiences with the effects of lignite mining, particularly the destruction of the landscape and nature. The interviewees from Uebigau-Wahrenbrück were generally positive toward wind energy, though one interviewee maintained that sustainability needed to be taken into account in the energy transition [interview \#15 of 28.05.21].

There are currently 21 wind turbines in a wind park situated on agricultural land between the communities of Uebigau and Beiersdorf, which are two parts of the City of Uebigau-Wahrenbrück. The wind park was developed in three stages, with 17 turbines built between 2005 and 2007, two in 2014, and two in 2016 and 2017 [138].

For 20 years, the expansion of wind energy in the federal state of Brandenburg has been governed by regional land-use planning; the Lausitz-Spreewald regional planning association governs the region containing Uebigau-Wahrenbrück. The advantage of this process, according to the regional planning office, is that it guarantees a fair distribution of wind turbines and sustainable implementation of energy projects. The goal is to build wind turbines in designated areas in order to avoid uncontrolled growth and impairment of the landscape [136]. In this regard, the regional planning office's role is to support 
municipalities, and project implementation is worked out between the municipality and the developer [interview \#15 of 28.05.21].

Despite support among the city council and regional planning office, protests against wind energy have arisen in the region, but these were not organized. Rather, the opposition "cut across many interest groups and parties" [152]. It was focused on unequal regional distribution of wind turbines, negative effects on the landscape, and the expectation of a negative influence on tourism [56, 152]. Unpleasant noise caused by the wind turbines was also a topic of complaints by local residents during the process of expanding the wind park in 2007 [75].

\section{Procedural Justice: information, consultation, decision-making}

The State of Brandenburg had decided to steer the selection of land for wind energy use via regional planning, which ultimately limits the decision-making authority of local governments [70]. In the regional planning process, only local governments from a certain size have co-determination and participation rights. One interviewee explained benefits of this regional approach to wind energy siting as including the ability to accomplish wind energy expansion without local pressures on mayors who might locate wind turbines in unsuitable areas or bow to pressure of private landowners; whereas, the regional level did not have to endure the same kind of political influence that mayors had [interview Uebigau-Wahrenbrück]. The regional planning office coordinates regional plans with the mayors before publication to exclude procedural errors [interview \#15 of 28.05.21]. It also assists local governments with project planning and implementation:

"Mayors frequently approach the regional planning agency and ask for their opinions on project sponsors. The regional planning agency has gained experience with many of them over the years. In addition, there is not as much self-awareness that is perhaps in the western states. Many mayors allow themselves to be led around by project developers. They allow themselves to be intimidated by arrogant project developers" [interview Uebigau-Wahrenbrück).

One interviewee stated that municipalities were motivated by the regional planning office to expand wind energy and had the opportunity to discuss concentration areas, but they were excluded from the regional planning process [interview \#4 of 23.02.21]; [95]. The interviewee further reported the failure of an attempt by the city to make a minor expansion of a designated area for wind energy in the regional land use plan process [interview \#4 of 23.02.21]. Despite a resolution of the city council [25], the regional planning association rejected the expansion due to lack of agreement with the regional plan, and to avoid a concentration of turbines and therefore potential grid congestion.

In recognition of the resulting lack of opportunity for some municipalities to participate in the regional planning association, the law has changed recently. The Brandenburg state parliament has authorized the inclusion of all municipalities - regardless of how small - in the regional planning assembly, starting in 2025 [81]. However, this poses challenges: 
"More democracy isn't possible. (. ..) This means a considerable amount of extra work. They will have to lead and organize meetings with over 100 participants. The politicians have decided to involve all of the municipalities, but they have left us alone with the consequences. That annoys me. This group is larger than the state parliament. I wish I had more support here" [interview \#15 of 28.05.21].

Citizen participation in the planning procedures in Uebigau-Wahrenbrück occurred in many forms. In addition to implementing public participation procedures according to legal requirements, information and training events were important instruments aimed at raising awareness of climate protection and creating understanding about the energy transition [interview \#4 of 23.02.21]. Additional information instruments included information events [76, 78, 148], renewable energy fairs [146], idea and cooperation exchanges [149], painting competitions [147], and school events [83]. The project sponsor also opened a citizens' office in Uebigau-Wahrenbrück [77]; [interviews \#4 of 23.02.21, \#7 of 28.05.21].

"In Uebigau, it [citizen participation, events, author's note] went through the citizens' office. That's rather rare. Otherwise, there are websites where one can get information, or in the context of participation sessions" [interview \#7 of 28.05.21].

From the perspective of one interviewee, however, municipalities have not only the right to fair procedures and distribution of costs and benefits, they also have duties. Following measures such as integrated urban development or transport development concepts, an interviewee proposed the mandatory creation of an energy concept for every municipality. Such a concept would address the expansion of renewable energies in a technology-open manner and be tied to financial transfers. In this way, measures could be holistic and long-term, and concepts could be protected from short-sighted political influence.

"They [municipalities, authors' note] have to work out the facts. These are often not known locally. (...) At the moment, those who want to and are interested in an energy concept are doing so, while the others are not. (...) Another complicating factor is that we in the region are AfD[7]-heavy. (...) And the AfD has no interest in transparency and facts. But if transparency is forced, then you have to justify locally why something is not possible. And then you also have to argue to your citizens, why you no longer get the money through the distribution mechanism. And if you do that well, you will be provided better allocations from the state government" [interview \#15 of 28.05.21].

While constitutional concerns stand in the way of mandating municipal energy concepts [137] ${ }^{[8]}$, the German Citizens' Climate Council, which recently concluded deliberations, recommends that policymakers establish mandatory municipal climate protection programs to implement climate neutrality in the energy sector [21].

Distributive justice: costs/benefits

Interviewees clearly stated a need for financial participation by citizens and host municipalities in wind energy projects [interview \#4 of 23.02.21]; [76], and there were strong concerns about a disadvantageous balance between costs and benefits: 
"There is only a notification policy. For 10 years, there were discussions about allowing municipalities to participate in revenues from wind energy expansion, or that the host municipality would receive a contribution, because the turbine operators are not locally owned. But nothing has been clearly decided. No implementation policy. This creates dissatisfaction, especially in rural areas. The municipality cannot have only a burden but should also have income. It must not be that an investment company in Munich earns from the wind turbines, but the host region does not even get tax revenue. Value creation must remain on site" [interview \#4 of 23.02.21].

In the case of Uebigau-Wahrenbrück, it was possible to compensate for this deficiency in part through urban development contracts. Revenues were used, for example, to refurbish a multipurpose building and develop a multigenerational meeting place. Additionally, under a new trade tax splitting rule enacted in May 2021, 90 percent of the trade tax from renewable energy now remains in the local municipality [18]. However, one interviewee criticized the lack of municipal authority to levy property taxes on wind parks [interview \#15 of 28.05.21]. A proposal by the federal government to grant municipalities property tax levy authority over wind park areas failed in the mediation committee of the two houses of the federal parliament in 2019 [14, 32].

Nevertheless, one interviewee saw improved participation opportunities for communities hosting wind turbines, noting that income generation and participation have become easier due to an amendment of the Renewable Energy Law (Section 36k) [interview \#7 of 28.05.21].

According to Section 36k of the Renewable Energy Law referenced by the interviewee, project developers can now offer financial compensation to affected communities. ${ }^{[9]}$ While this was initially intended to be a mandatory provision, it became a voluntary measure after negotiations in federal parliament [34].

Despite the interest of the citizens of Uebigau-Wahrenbrück in a citizen participation model [82], an option for financial participation by citizens was not found until 2017. Earlier plans failed, among other reasons, due to demands of the Federal Financial Supervisory Authority [interview \#7 of 28.05.21]; [78]. However, since the beginning of 2018, the project developer has offered a citizen savings model in cooperation with a financial institution, through which investors can invest between 500 and 15,000 euros at a fixed interest rate of 4 percent [139].

The low number of citizen wind parks, particularly in eastern German states, is also due to the historically evolved land ownership structure, according to an interviewee. Land is mostly managed by agricultural companies, which means there are fewer individual landowners [interview \#7 of 28.05.21]. Another interviewee stated:

"Agricultural cooperatives are owners of huge areas of land. (...) They are big and strongly represent their interests, but they are not always in the interest of the common good. As an example: after two dry summers, photovoltaic parks were laid over still productive arable land. This is not in the interest of sustainability. But they earn more money with photovoltaics than cultivating these fields. (...) It is 
becoming more and more difficult here to reconcile the interests of land users with aspects of sustainability" [interview \#15 of 28.05.21].

Beyond financial participation opportunities in the wind turbines, citizens of Uebigau-Wahrenbrück have benefited from cooperation with the project developer. Benefits have included sponsored events, the supply of "wind cases" for a mobile teaching unit of a local educational academy and support for city festivals [interview \#4 of 23.02.21].

In addition to financial aspects, attention was paid in the project planning and construction phase to compensating for encroachments on and impairment of the landscape through renaturation projects, nature conservation funds and measures such as orchards and tree planting [interview \#4 of 23.02.21].

Despite financial participation opportunities and general willingness to build more wind energy plants, interviewees desired more regional equity (inter-regional, urban-rural) as well as mandatory photovoltaics on buildings [interviews \#4 of 23.02.21, \#15 of 28.05.21].

In addition to procedural and distributive justice, the issue of higher-level conflicts between goals was also raised. One interviewee found lacking a debate on values about the way of life and advantages and disadvantages of a centralized or decentralized power supply on all levels of society [interview \#15 of 28.05.21]. Another interviewee would have liked to see more local participation in national decisions:

"It is always decided top-down, EU Green Deal, national targets, country targets. Citizens are also often not taken seriously. I was once with students at the Federal Ministry. They often live in a haze and have no idea how things work at the grassroots level. They should have talked to the people. (...) Setting targets is okay. Maybe they didn't know about the consequences and regional impacts. But the tax consequences, [lack of trade tax income, authors' note], that should have been done right away. They decide in Berlin and nobody asks us" [interview \#4 of 23.02.21].

[2] The average in Lower Saxony is 167 inhabitants per $\mathrm{km}^{2}$.

${ }^{[3]}$ National average: 22,899 euros per capita.

[4] The wind turbines are located in the Wadlhauser Gräben forest in the Starnberger See-Ost conservation area. The community of Neufahrn is about one kilometer and the center of the Schäftlarn municipality about 1.5 kilometers northeast, Irschenhausen and Icking are about two kilometers southeast and Berg three kilometers southwest of the plants [22].

${ }^{[5]}$ Several interviewees stated that the mayor of Berger personally faced the critical questions of the neighboring community comprehensively [interviews \#5 of 23.02.21, \#13 of 27.04.21].

[6] Bavaria's "refusing to use wind energy" is a reference to and ultimately resulted in the state's so-called '10-H Rule', which generally requires that wind turbines must be located a minimum distance from residential areas of at least 10 times the height of the turbine. The result of this rule, which went into effect in 2014, was to substantially slow down wind energy expansion in Bavaria [17]. 
${ }^{[7]}$ AfD refers to the right-wing populist political party "Alternative for Germany" (Alternative für Deutschland).

[8] The German Constitution precludes the federal government from establishing new tasks for municipalities in a directly binding manner (Art. 84, Abs. 1, S. 7, Grundgesetz).

[9] "Affected municipalities" means those which are located within 2,500 meters of a wind turbine.

\section{Discussion}

This study examines how procedural and distributive justice can help build bridges in local wind energy projects and identifies important factors that can lead to consensus building or facilitate compromise. Our focus is on the concept of societal sponsorship - the willingness of actors to tolerate decisions despite their opposition. Following the literature on energy justice, the cases of conflict over wind energy expansion were analyzed according to two dimensions: procedural justice and distributive justice. Elinor Ostrom's IAD was drawn from as well to structure the analysis.

This study confirms that societal sponsorship is a highly relevant concept to analyze compromises and the potential to build bridges between conflicting interests in the expansion of wind energy projects. On the one hand, the interviewees emphasized that "acceptance" - in the form of active positive local support - can hardly be achieved, given conflicting goals and interests related to wind energy expansion. There will always be residents who will be critical of the introduction of wind energy. However, these critical actors may tolerate wind energy projects and refrain from taking action against the projects if distributive and procedural justice are adequately addressed. It is this form of tolerance, based on distributive and procedural justice, that we conceptualize as societal sponsorship.

In addition, this study confirms our theoretical argument that it is necessary to remove the artificial separation between the analytical dimensions "community acceptance" and "socio-political acceptance", as described, for example, in Wüstenhagen et al. [151]. As mentioned above, there is not only acceptance/support or opposition in the debate about wind energy, there can also be a form of tolerance, i.e., societal sponsorship.

Further, local actors expect to be included in the debate about the energy transition and, in particular, the expansion of wind energy, especially since it affects them locally [151]. In particular, societal sponsorship can be enhanced through integration of the procedural aspect of energy justice. This is linked to citizens' demands for a debate about the energy transition by society as a whole. We find that critical actors were willing to come to terms with, or tolerate, the expansion of wind energy if they were involved in and had an opportunity to be heard at an early stage of the planning process. This is achieved through willingness of local governments and project developers to provide intensive, individual support, and to offer tailored solutions to problems.

Procedural Justice 
Procedural justice, as an aspect of energy justice, is aimed at providing procedural transparency, access to objective and comprehensive information, the exchange of information, early involvement in the project process, the opportunity to be heard, the consideration of citizen's arguments and their integration in the process, and the recognition of unfair procedures [97].

Local decision-makers in the selected cases made clear that they consider their cooperation in the expansion of wind energy to be a compromise. In return, they expected some control over both the process and design of the projects, in order to achieve more fair distribution of costs and benefits for their citizens, as well as to increase the benefits to their municipalities and citizens. These aims could be achieved through early involvement in the project planning processes and by taking local needs into account. Therefore, we recommend that options for actions by municipalities be strengthened.

Project developers play a central role, as this is the main point of contact in the planning and implementation of energy projects. Where the developer was more willing to respond individually to needs and concerns of local actors and citizens and to deal intensively with the reservations of citizens and find creative solutions, the willingness to compromise was greater. This had the effect of counteracting feelings of powerlessness among local actors. In particular, some interviewees were positive about measures such as joint site inspections. These measures could also be extended to neighboring communities. We also found that transparency, objectivity and openness in the processes increased the trust of local actors.

As a result of our findings, we recommend that project developers cooperate with affected local governments regarding location, turbine height, number of turbines, and the like, and develop standards for fair procedures. With regard to fair procedures, certification labels for fair wind energy have been discussed by other authors [see e.g. 29, 153], and this could be a solution. Some interviewees were indifferent to this type of instrument ${ }^{[10]}$, but a "fair wind energy" label could increase transparency about the manner in which project developers operate. Confidence in this instrument could be increased if organized by impartial public institutions such as energy agencies. An additional benefit could arise from the access to a pool of experts or neutral moderators, who could, for example, be called into difficult public events and who could voluntarily submit to a code of conduct. Project developers could also be supported by opportunities for pooling knowledge on procedures, technical developments or new regulations. For example, technical innovations that improve protection of species, nature and health and reduce nuisances (flickering, shadows, noise, endangerment of animals by rotor blades, etc.) associated with wind turbines can be used to reduce burdens created at wind park sites. Promising approaches to this can be found in the form of a wind energy handbook [1] and studies on environmental energy law [143], which should be regularly updated and expanded to include best practice examples [99].

The municipalities' demands for autonomy to act and for opportunities to exert influence over the expansion of wind energy appeared easier to achieve in municipalities that controlled the expansion of wind energy through land use plans and have municipally-owned land at their disposal. In contrast, early community involvement in the process was more difficult where land use designations were controlled by 
regional planning. In these cases, regional planning authorities played a key role because regional control of land designation can initially preclude individual agreements between municipalities and project developers, or municipalities could only enter these agreements within the regional planning framework. This dilemma could be mitigated by the expansion of eligibility for membership in regional planning assemblies, which has been limited to municipalities having a certain minimum number of inhabitants. An example of an expanded membership policy is found in Brandenburg, where all municipalities will be included in regional planning assemblies starting from 2025. This step should be accompanied by better staffing and technical support for regional planning bodies, in order to ensure the quality of coordination and decision making.

As previously described, a hurdle for many municipalities is that they do not own land suitable for construction of wind turbines. Particularly in the eastern federal states of Germany, agricultural cooperatives are large landowners. In these cases, the urban development contract is an instrument that provides a means of controlling aspects of wind park projects, including height, number of turbines, and type of public participation measures. This instrument, which is defined in the Building Code ${ }^{[11]}$, gives municipalities room to negotiate agreements to promote renewable energy [137]. Development plans also offer municipalities limited design options ${ }^{[12]}$. This is an area where municipalities should be strengthened. Municipal actors should have access to advisory services for support in drafting contracts and for planning questions. Such advisory services could be linked to existing organizations such as the German Competence Center for Nature Conservation and Energy or the Specialist Agency for Onshore Wind Energy, both of which have a high level of expertise and already have offers for municipalities.

We observe that, at the municipal level, wind energy projects are often promoted by the mayor and municipal council, as well as the district administrator. These are actors who - in the examples that we studied - took positions in favor of the projects and commit to them. As a result, opponents of wind energy projects can have the impression that their concerns are not considered in an unbiased manner. However, the municipal actors driving the project typically view themselves as representing all citizens' interests with the goal of working out compromises to achieve a balanced distribution of costs and benefits, which contradicts possible concerns of an existing bias of these actors.

\section{Distributive Justice}

Distributive justice refers primarily to the distribution of costs and benefits such as siting of wind turbines, choice of energy sources, ownership issues, revenues, and compensation measures [97].

Among the local decision-makers interviewed for our analysis, the increase in local added value from wind parks played a central role. Those benefitting from wind park revenues should preferably not be individual actors, but the community as a whole. For example, revenues from wind energy can be used to replenish empty municipal coffers and provide funding for the common good. The revenue opportunities of municipal governments in Germany have recently improved due to a new trade tax splitting rule introduced in 2021. To complement this, some interviewees expressed a desire to give municipalities the 
right to levy a property tax increment on wind parks. However, plans to change the applicable tax law to enable this failed in 2019 in negotiations in the German parliament. A resumption of these plans is recommended. A further tax law option to improve municipal income from wind projects could be achieved through improved depreciation options for project developers. By improving the depreciation framework, wind turbines could more rapidly generate profits, and municipalities would thus more quickly receive the benefit of income tax.

In the case of the municipality of Berg, financial participation in the citizens' wind project played a major role in municipal value creation. Based on experience from this project, a priority allocation of shares to local actors (municipal and private investors) is recommended. However, when developing financial participation models, the economic situation of the region should be taken into account. In UebigauWahrenbrück, for example, plans for a citizens' wind turbine project could not be realized; rather, the developer, in cooperation with a financial institution, set up a program for citizens' wind savings accounts, in which even small investments of a few hundred euros were possible.

In the case of Berg, conflict with a neighboring community formed the core of the protests against the construction of wind turbines. Although the Renewable Energy Law now authorizes compensation payments for affected communities which are located within 2,500 meters of a wind turbine, this is only an option and not a mandate. It is therefore recommended that financial compensation for neighboring communities become an obligation under the Renewable Energy Law. The offer of financial compensation for affected residents was evaluated varyingly by interviewees. Instead of direct financial compensation to affected citizens, it is recommended that project developers develop solutions together with local actors. In Brake, for example, owners of the land on which the wind park was constructed, have given the people of Brake a share of their income from wind energy through a support association. Developers have also compensated for disadvantages of wind turbines through creative offers; these include free building surveys, purchase of shutters for residential buildings, and compensation for loss of value of residential property.

Another distributive justice issue raised was the unequal distribution of costs and benefits between regions and between urban and rural areas, which was criticized in several interviews. In terms of interregional justice, it is recommended that the construction of wind turbines in federal states with a low expansion quota be promoted. First steps in this direction have been taken: in the Renewable Energy Law of 2021, inter-regional distributive justice can be achieved through a "southern quota," which aims to encourage a greater share of wind energy expansion in the south of Germany ${ }^{[13]}[96,145]$. At the same time, regional planning bodies should agree to negotiate an expansion of their existing wind parks with municipalities that are willing to expand, even if the regional planning body views this as being in conflict with the principle of sustainable and balanced management. The unequal treatment of municipalities could also be reduced by a mandatory energy and climate concept, which should include renewable energy potential. The German Citizens' Climate Council also recommends mandatory municipal climate protection programs to implement climate neutrality in the energy sector [21]. Due to constitutional constraints $^{[14]}$, the development of a legally valid model is advisable. 
With regard to urban-rural equity, various interviewees called for an obligation to install solar panels, at a minimum, on all public buildings. This obligation should also be extended to new buildings, and the suitability of existing buildings should be assessed ${ }^{[15]}$. In this context, barriers such as roof warranties, monument protection, and limitations on installation imposed by homeowners' associations should be removed.

\section{Coherence}

In addition to the aspects of procedural and distributive justice, which were prominent themes in the interviews, some interviewees expressed doubts about the coherence of Germany's energy transition. In this context, an honest and transparent discussion about conflicting goals in the energy transition is needed. Interviewees raised the need to address societal values with regard to the energy transition and demand for an open debate. All opportunities and risks, advantages and disadvantages, should be on the table, and a compromise worked out for society as a whole. This would be preceded by a discussion about our way of life, incentives for saving energy, and openness to technology. The advantage of taking an approach which includes an open debate about the energy transition is that implementation can then be better secured by societal sponsorship.

[10] In addition to doubts about the meaningfulness of a certification label, including differing understandings of the meaning of "fair", there were also doubts about the about the necessity of the label (label overload, just a clever business idea, etc.) [interviews \#4 of 23.02.21, \#10 of 16.03.21, \#15 of 28.05.21].

[11] Urban development contracts are provided for pursuant to Section 11(1), no. 4, BauGB.

${ }^{[12]}$ Section 9, BauGB.

[13] The "southern quota" refers to plans to encourage the expansion of wind energy particularly in the states of Bavaria and Baden-Württemberg in southern Germany, by creating an adjusted compensation model for municipalities [145].

[14] Under Article 84 (1) sentence 7 of the German Constitution, the federal government is prevented from directly assigning new municipal tasks to the municipalities in a binding manner [137].

[15] The Federal Environment Ministry wanted to introduce mandatory installation of photovoltaic or solar thermal systems on new buildings and major roof renovations with the Renewable Energy Law in 2021, but failed to do so because of the Federal Ministry of Economics [31].

\section{Conclusions}

The following central results of the case analysis can be summarized:

1. Local lines of conflict mainly run along the dimension of distributive justice (costs and benefits).

2. Procedural justice is a necessary condition for agreement with decisions made by higher political levels. 
3. Local, ideally community-level value creation is the main argument of local decision makers to justify expansion of wind energy.

4. As a consequence, the benefits at the local level need to be increased, with the aim of achieving a balance of costs and benefits.

5. Key local actors for the successful expansion of wind energy are mayors, municipal councils, and project developers.

6. Some citizens associate the lack of involvement in national decision-making with doubts about the coherence of the energy transition, and ask for a society-wide debate about the values and goals of the energy transition.

7. (Critical) actors may tolerate a wind project and refrain from taking action against wind energy projects (societal sponsorship) if distributive and procedural justice are adequately addressed.

8. This study has shown that limited local opportunities for action have a negative impact on the tolerance of wind energy projects. Local actors try to expand their scope of action and maximize the benefits of energy transition projects for local residents. If this succeeds, the acceptability of the projects or the willingness to compromise increases.

9. The study also confirms the importance of distributive justice as a factor in the Energy Justice concept. Within the scope of the study, it became clear that distributive justice is essentially achieved through political instruments such as increasing municipal value creation, financial participation, opportunities for community wind savings accounts, financial compensation payments, fair taxation, regional distribution, mandatory energy and climate concepts, or an obligation to install photovoltaic systems.

These findings should be supplemented by further research. In this context, it would be worthwhile to broaden the focus of this study and to examine how the interests of additional groups of actors such as project developers influence the energy transition, what this means for the societal sponsors (especially local actors) of the energy transition and, finally, how a balance between the varying interests of these different interest groups can be achieved. We also see a need for further research on intermediary actors and instruments. Furthermore, more knowledge is needed that analyses citizens' understanding of the energy transition, which goes beyond supplying the place of residence with renewable energy. The aim of such research should be on the one hand to incorporate local knowledge, on the other hand to conduct a technology-open debate and finally to explore the willingness of citizens to change their own lifestyles.

\section{Abbreviations}

AFA: $\quad$ Absetzung für Abnutzung (Depreciation deduction for wear and tear)

AFD: $\quad$ Alternative für Deutschland (Alternative for Germany)

BauBG: $\quad$ Baugesetzbuch (Building Code)

IAD: $\quad$ Institutional Analysis and Development framework 
$\mathrm{km}^{2}: \quad$ square kilometers

MW: $\quad$ megawatts

NABU: $\quad$ Naturschutzbund (Nature Conservation Association)

\section{Declarations}

Ethics approval and consent to participate

Not applicable.

\section{Consent for publication}

Not applicable.

\section{Availability of data and materials}

Interviews were conducted on the basis of the guarantee of anonymity. The summaries of the interviews are available from the corresponding author on reasonable request.

\section{Competing interests}

The authors declare no conflict of interest.

\section{Funding}

This research is part of the Kopernikus project ARIADNE and was kindly funded by the German Federal Ministry of Education and Research.

\section{Author's Contribution}

DO and SR conceptualized the study and developed its methodology. SR collected the data and conducted the analysis. LG supported data collection to verify interview data. SR prepared the original draft supported by LG. DO reviewed and edited the manuscript and supervised the study. All authors have read and agreed to the published version of the manuscript.

\section{Acknowledgments}

The authors wish to thank Arwen Colell for constructive comments on the paper. The authors also wish to thank their colleagues at the Institute for Environment and Climate Policy at the Technical University of Munich for their helpful tips on setting up the study. The authors also wish to thank all interview participants for taking the time to participate in this project and their valuable input, and all anonymous reviewers who reviewed the work and provided feedback. 
This article is based on the report, Lokale Konfliktlinien und Brückenpotentiale beim Ausbau der Windenergie in Deutschland: Zwischen unterschiedlichen Interessen, Werten und Prioritäten, a publication prepared as part of the Kopernikus project Ariadne. The article encompasses translation, modification, and expansion of parts of the previously published report.

\section{Corresponding author}

Correspondence to Sybille Reitz

\section{References}

1. Agatz, M. (2020). Windenergie-Handbuch (1 $7^{\text {th }}$ edn). Gelsenkirchen.

2. Agentur für Erneuerbare Energien (2021, January 7). Zustimmung für den Ausbau der Erneuerbaren Energien bleibt hoch. https://www.unendlich-viel-energie.de/themen/akzeptanzerneuerbarer/akzeptanz-umfrage/zustimmung-fuer-den-ausbau-der-erneuerbaren-energien-bleibthoch. Accessed 7 January 2021.

3. Alex, P. (2018, October 16). Energiekontor feiert Einweihung des Windparks Hammelwarder Moor ausreichend Strom für umliegende Bevölkerung. https://www.energiekontor.de/aktuelles/2018-10-16energiekontor-feiert-einweihung-des-windparks-hammelwarder-moor-ausreichend-strom-fuerumliegende-bevoelkerung.html.

4. Ammer, A. (2016, May 4). Gestern im Gemeinderat - ans Eingemachte. https://quh-berg.de/gesternim-gemeinderat-das-eingemachte-14636340/. Accessed 28 June 2021.

5. Amtliches aus Kefenrod (2013, April 26). TOP 9 Herr Bürgermeister Bernd Kling informiert. Amtliches aus Kefenrod, p. 3.

6. Bader, S. (2011, March 14). Gegenwind für Genz. Windrad-Streit: Entscheidung vertagt. Süddeutsche Zeitung. https://www.sueddeutsche.de/muenchen/starnberg/windrad-streit-entscheidung-vertagtgegenwind-fuer-genz-1.1036840. Accessed 28 June 2021.

7. Bader, S. (2011, November 4). Wo sich Windräder drehen sollen. sueddeutsche.de. https://www.sueddeutsche.de/muenchen/starnberg/landkreis-starnberg-wo-sich-windraeder-drehensollen-1.1180447. Accessed 5 July 2021.

8. Bader, S. (2013, October 14). „Jetzt ist Krieg“. Süddeutsche Zeitung, R9.

9. Batel, S. (2017). A critical discussion of research on the social acceptance of renewable energy generation and associated infrastructures and an agenda for the future. Journal of Environmental Policy \& Planning, 20(3), 356-369. doi:10.1080/1523908X.2017.1417120.

10. Batel, S., Devine-Wright, P., \& Tangeland, T. (2013). Social acceptance of low carbon energy and associated infrastructures: A critical discussion. Energy Policy, 58, 1-5. doi:10.1016/j.enpol.2013.03.018.

11. Baur, F., Currin, A., Noll, F., Rau, I., Wern, B., Boenigk, N., et al. (2017). Kommunen als Impulsgeber, Gestalter und Moderator der Energiewende - Elemente energienachhaltiger Governance: 
EnGovernance FKZ 0325764 Abschlussbericht. Saarbrücken/Berlin.

12. Bayerische Staatsforsten (n.d.). Windenergie. https://www.baysf.de/de/waldbewirtschaften/regenerative-energien/wind.html. Accessed 28 June 2021.

13. Bayernwerk (n.d.). Berg - Energiemonitor: Erzeugung - Verbrauch - Entwicklung der Eigenversorgung, Entwicklung des Anteils regenerativer Energien. https://energiemonitor.bayernwerk.de/berg? autoscroll=1\&seconds=15. Accessed 5 July 2021.

14. BDEW (2019). Kerstin Andreae zu den heutigen klimapolitischen Beschlüssen des Bundesrates. Statement für die Presse. o. 0 .

15. BI Gegenwind im Hammelwarder Moor (2015). Stoppt den Ausbau des Windparks Hammelwarder Moor: Petition richtet sich an Bürgermeister Herr Kurz / Bürgermeister Herr C. Hartz. https://www.openpetition.de/petition/online/stoppt-den-ausbau-des-windparks-hammelwardermoor?language=de_DE.utf8. Accessed 2 July 2021.

16. Bremerhavener Gesellschaft für Investitionsförderung und Stadtentwicklung mbH (o. J.). Wasserstoff - Neuer Energieträger und Wirtschaftsmotor für Bremerhaven: H2BrakeCO2. https://www.bis-bremerhaven.de/wirtschaftsstandort/wasserstoff.99406.html. Accessed 13 December 2021.

17. BUND Landesfachgeschäftsstelle München (2019, November 21). CSU-Spitze nimmt Bayern den Wind aus den Segeln. 5 Jahre 10-H-Regelung gegen die Windenergie in Bayern. https://www.bundnaturschutz.de/pressemitteilungen/fuenf-jahre-10-h-regelung-gegen-die-windenergie-in-bayern. Accessed 25 October 2021.

18. Bundesrat (2021). Gesetz zur Stärkung des Fondsstandorts Deutschland und zur Umsetzung der Richtlinie (EU) 2019/1160 zur Änderung der Richtlinien 2009/65/EG und 2011/61/EU im Hinblick auf den grenzüberschreitenden Vertrieb von Organismen für gemeinsame Anlagen (Fondsstandortgesetz - FoStoG): Drucksache 354/21 (Beschluss).

19. Bundesverfassungsgericht (2021, April 29). Verfassungsbeschwerden gegen das Klimaschutzgesetz teilweise erfolgreich: Beschluss vom 24. März 2021. Pressemitteilung Nr. 31/2021. https://www.bundesverfassungsgericht.de/SharedDocs/Pressemitteilungen/DE/2021/bvg21031.html. Accessed 8 June 2021.

20. Bürgerbeteiligung (n.d.). Bürgerbeteiligung: Die Energiewende gelingt nur als Gemeinschaftsprojekt. https://www.bundesregierung.de/breg-de/themen/energiewende/fragen-undantworten/allgemeines/buergerbeteiligung-455794. Accessed 6 January 2021.

21. Bürgerrat Klima (2021). Empfehlungen für die deutsche Klimapolitik: 160 Menschen, 12 Sitzungen, 1 Thema. Bürgerrat Klima 26.04. - 23.06.2021. Berlin.

22. Bürgerwind Berg GmbH \& Co. KG (n.d.). Windenergie in den Wadlhauser Gräben. Bürgerwind Berg GmbH \& Co. KG. http://www.buergerwind-berg.de/projektinformation/. Accessed 28 June 2021.

23. Burgess, P. J., Rivas Casado, M., Gavu, J., Mead, A., Cockerill, T., Lord, R., et al. (2012). A framework for reviewing the trade-offs between, renewable energy, food, feed and wood production at a local level. Renewable and Sustainable Energy Reviews, 16(1), 129-142. doi:10.1016/j.rser.2011.07.142. 
24. Charisius, H., Bahnmüller, P., Biener, J. K., Laufmann, P., Pataczek, A., Schrenk, J., et al. (2011). 2011 Bayerische Staatsforsten: Jahresbericht. Regensburg.

25. Claus, A. (14.11.12). Öffentliche Auslegung des Vorentwurfs Sachlicher Teilflächennutzungsplan „Windkraftnutzung" der Stadt Uebigau-Wahrenbrück gemäß § 3 Abs. 1 BauGB: Frühzeitige Beteiligung der Öffentlichkeit. Amtsblatt für die Stadt Uebigau-Wahrenbrück, p. 3.

26. Colell, A. (2021). Alternating Current - Social Innovation in Community Energy (1st edn, Energiepolitik und Klimaschutz. Energy Policy and Climate Protection). Wiesbaden: Springer Fachmedien Wiesbaden; Imprint: Springer VS.

27. Cowell, R., Bristow, G., \& Munday, M. (2011). Acceptance, acceptability and environmental justice: the role of community benefits in wind energy development. Journal of Environmental Planning and Management, 54(4), 539-557. doi:10.1080/09640568.2010.521047.

28. Demuth, B., Heiland, S., Luick, R., Vedel, D., Ammermann, K., \& Wiersbinski, N. (Eds.) (2016). Die Energiewende im Spannungsfeld energiepolitischer Ziele, gesellschaftlicher Akzeptanz und naturschutzfachlicher Anforderungen: Ergebnisse des gleichnamigen F+E-Vorhabens (FKZ 3515801800) des Bundesamtes für Naturschutz (BfN-Skripten, Vol. 433). Bonn-Bad Godesberg.

29. Di Nucci, M. R., \& Krug, M. (2018). Akzeptanz von Windenergie in Regionen mit schwachem Windenergieausbau. Dekarbonisierung - Akzeptanz. Energiewirtschaftliche Tagesfragen, 68(4), 4043.

30. Di Nucci, M. R., Krug, M., Will, A., \& Vondran, S. (2020). Akzeptanzfaktoren und akzeptanzfördernde Maßnahmen beim Ausbau der Windenergie. et - Energiewirtschaftliche Tagesfragen, (4), 29-34.

31. Enkhardt, S. (2021). Photovoltaik-Pflicht steht im "Sofortprogramm Klimaschutz 2022“ auf der Kippe.

32. Finkenwirth, A. (2019, December 19). Vermittlungsausschuss stoppt Grundsteuer Wind - DBV: Vorrang für Beteiligungsmodelle bei Windparks. finanznachrichten.de. https://www.finanznachrichten.de/nachrichten-2019-12/48461856-vermittlungsausschuss-stopptgrundsteuer-wind-dbv-vorrang-fuer-beteiligungsmodelle-bei-windparks-007.htm. Accessed 07.07.21.

33. Fischer, W., Hake, J.-F., Kuckshinrichs, W., Schröder, T., \& Venghaus, S. (2016). German energy policy and the way to sustainability: Five controversial issues in the debate on the "Energiewende". Energy, 115(Part 3), 1580-1591. doi:10.1016/j.energy.2016.05.069.

34. Franke, P. (19.10.20). Windkraft an Land bleibt Sorgenkind. EEG-Novelle. energiezukunft.eu. https://www.energiezukunft.eu/erneuerbare-energien/wind/windkraft-an-land-bleibt-sorgenkind/. Accessed 07.07.21.

35. Frankfurter Allgemeine Zeitung (2013, March 4). Vier Windkraftanlagen bei Kefenrod genehmigt. Frankfurter Allgemeine Zeitung, Rhein-Main-Zeitung, p. 39. https://fazarchiv.faz.net/faz-portal/fazarchiv?q=Vier+Windkraftanlagen\&source=\&max=10\&offset=0\&searchln=TI\&\&_ts=1639390280051. Accessed 3 July 2021.

36. Fraune, C. (2020). Energy Democracy and Participation in Energy Transitions. In M. Knodt \& J. Kemmerzell (Eds.), Handbook of Energy Governance in Europe (pp. 1-18). Cham: Springer Nature Switzerland. 
37. Freels, D., Ideler, H., \& Gerwin-Heiß, B. (2015). Wir fordern eine verantwortungsvolle, bürgernahe und umsichtige Windenergieplanung im LK Wesermarsch: Petition richtet sich an Landrat Thomas Brückmann. https://www.openpetition.de/petition/online/wir-fordern-eine-verantwortungsvollebuergernahe-und-umsichtige-windenergieplanung-im-lk-wesermarsch?language=de_DE.utf8. Accessed 2 July 2021.

38. Fuchsenberger, S. (2021). Neues aus dem Gemeinderat: die Sitzung vom 18.05.2021: Ein Kommentar von GR Sissi Fuchsenberger (SPD). Kommentieren.

39. Fuller, S., \& McCauley, D. (2016). Framing energy justice: perspectives from activism and advocacy. Energy Research \& Social Science, 11, 1-8. doi:10.1016/j.erss.2015.08.004.

40. Gawel, E., Korte, K., \& Tews, K. (2015). Distributional Challenges of Sustainability Policies-The Case of the German Energy Transition. Sustainability, 7(12), 16599-16615. doi:10.3390/su71215834.

41. Gawel, E., Lehmann, P., Korte, K., Strunz, S., Bovet, J., Köck, W., et al. (2014). The future of the energy transition in Germany. Energy, Sustainability and Society, 4(1), 1-9. doi:10.1186/s13705-014-0015-7.

42. Gemeinde Berg (n.d.). Aktuelles zur Energiewende: Bauen und Umwelt. Windenergie in Berg. https://www.gemeinde-berg.de/Aktuelles.01809.html. Accessed 28 June 2021.

43. Gemeinde Berg (n.d.). Beteiligung Bürgerwind Berg GmbH \& Co. KG: Bauen \& Umwelt - Windenergie in Berg. https://gemeinde-berg.de/Beteiligung-Buergerwind-Berg-GmbH-Co.-KG.n194.html. Accessed 28 June 2021.

44. Gemeinde Berg (n.d.). Energiewende in Berg. Bauen \& Umwelt - Windenergie in Berg. https://www.gemeinde-berg.de/Energiewende-in-Berg.n132.html. Accessed 28 June 2021.

45. Gemeinde Berg (n.d.). Gemeinde Berg - Leben \& Wohnen: Über Berg. https://www.gemeindeberg.de/Ueber-Berg.n3.html. Accessed 28 June 2021.

46. Gemeinde Berg (n.d.). Hintergrund zur Windenergie. Bauen \& Umwelt. https://www.gemeindeberg.de/Hintergrund.n135.html. Accessed 28 June 2021.

47. Gemeinde Kefenrod. Zahlen und Fakten. https://www.gemeinde-kefenrod.de/seite/119421/zahlenund-fakten.html. Accessed 2 July 2021.

48. Giers, M. (2009, July 3). Über geplanten Windenergiepark soll sachlicher diskutiert werden: Forderung von Planer Arie Bakker - Information des Anliegers in Kefenrod seien falsch. Lokales. Kreis-Anzeiger. https://www.genios.de/presse-archiv/artikel/KRAN/20090703/-ber-geplanten-windenergieparksoll/2108158890001246572000.html. Accessed 13 December 2021.

49. Glückselig, D. (2014, March 16). Windparks auf zwei Flächen möglich. NWZonline. https://www.nwzonline.de/wesermarsch/wirtschaft/windparks-auf-zwei-flaechenmoeglich_a_13,6,1378096781.html. Accessed 1 July 2021.

50. Glückselig, D. (2014, June 13). Anlieger im Moor sind besorgt. NWZonline. https://www.nwzonline.de/wesermarsch/wirtschaft/anlieger-im-moor-sindbesorgt_a_15,0,1328217901.html. Accessed 1 July 2021.

51. Glückselig, D. (2015, March 21). Investor plant 150-Meter-Anlagen. NWZonline. https://www.nwzonline.de/wesermarsch/wirtschaft/investor-plant-150-meter- 
anlagen_a_25,0,1146681437.html. Accessed 7 June 2021.

52. Glückselig, D. (2015, April 2). Keine XXL-Mühlen auf Braker Gebiet. NWZonline. https://www.nwzonline.de/wesermarsch/wirtschaft/keine-xxl-muehlen-auf-brakergebiet_a_26,0,394888469.html. Accessed 5 July 2021.

53. Glückselig, D. (2015, April 8). Windpark: Investor stellt Pläne vor. NWZonline. https://www.nwzonline.de/wesermarsch/politik/windpark-investor-stellt-plaenevor_a_26,0,995985057.html. Accessed 5 July 2021.

54. Glückselig, D. (2015, May 30). WGB: Vor Entscheidung mit Anwohnern reden. NWZonline. https://www.nwzonline.de/wesermarsch/politik/wgb-vor-entscheidung-mit-anwohnernreden_a_28,0,1944366668.html. Accessed 6 July 2021.

55. Haacke, P. (2014, December 19). Ansturm auf die Windkraft: Das Angebot zur Bürgerbeteiligung stößt in Berg auf große Resonanz. Neufahrner protestieren erneut. Süddeutsche Zeitung, R7.

56. Hilberg, F., \& Kunze, S. (2005, October 27). Uebigauer Windpark wird weiter wachsen. Lausitzer Rundschau Online. https://www.Ir-online.de/lausitz/herzberg/uebigauer-windpark-wird-weiterwachsen-35163784.html. Accessed 4 July 2021.

57. Hildebrand, J., Rau, I., \& Schweizer-Ries, P. (2018). Akzeptanz und Beteiligung - ein ungleiches Paar. In L. Holstenkamp \& J. Radtke (Eds.), Handbuch Energiewende und Partizipation (pp. 195-209, Handbuch). Wiesbaden: Springer VS.

58. Hock, C. (2015, July 16). Verhärtete Fronten im Windpark-Streit. Energie. NWZonline. https://www.nwzonline.de/wesermarsch/politik/verhaertete-fronten-im-windparkstreit_a_30,0,711914102.html. Accessed 2 July 2021.

59. Hock, C. A. (2015, July 4). Bürgerinitiative will vor Gericht ziehen. Windenergie. NWZonline. https://www.nwzonline.de/wesermarsch/wirtschaft/buergerinitiative-will-vor-gerichtziehen_a_29,0,3364151244.html. Accessed 2 July 2021.

60. Hübner, G., Pohl, J., Warode, J., Gotchev, B., Ohlhorst, D., Krug, M., et al. (2020). Akzeptanzfördernde Faktoren erneuerbarer Energien. Bonn.

61. Hügenell, I. (2013, February 27). Einseitig belastet: Bürgermeister begründet Schäftlarns Klage gegen Windräder. Süddeutsche Zeitung, R9.

62. Hügenell, I. (2013, July 24). Windkraftgegner werfen Gutachter Verfälschung vor: Der Ton wird schärfer: Die Bürgerinitiative zum Schutz der Wadlhauser Gräben bezweifelt Aussagen zu Rotmilanen. https://www.sueddeutsche.de/muenchen/wolfratshausen/sind-die-voegel-verjagtworden-windkraftgegner-werfen-gutachter-verfaelschung-vor-1.1730051. Accessed 1 July 2021.

63. Hügenell, I. (2015, February 12). Schäftlarn hofft auf den Wespenbussard. https://www.sueddeutsche.de/muenchen/wolfratshausen/schaeftlarn-berg-schaeftlarn-hofft-aufden-wespenbussard-1.2349275. Accessed 1 July 2021.

64. IFE Ericksen (n.d.). Projekte: Wind- und Solarkraftprojekte. http://ife-eriksen.de/projekte/. Accessed 1 July 2021. 
65. innoVent GmbH (n.d.). Windpark “Brake”. https://innovent.eu/referenzen/deutschland/brake/. Accessed 13 December 2021.

66. Jauken, G. (2015, June 12). Widerstand gegen Windparks. Bürgerinitiativen in Brake, Golzwarden und Ovelgönne gegründet. Weser-Kurier.de. https://www.weser-kurier.de/bremen/widerstand-gegenwindparks-doc7e3I0xsviwm6wc9cjms. Accessed 2 July 2021.

67. Jenkins, K., McCauley, D., Heffron, R., Stephan, H., \& Rehner, R. (2016). Energy justice: A conceptual review. Energy Research \& Social Science, 11, 174-182. doi:10.1016/j.erss.2015.10.004.

68. Kalt, T. (2021). Jobs vs. climate justice? Contentious narratives of labor and climate movements in the coal transition in Germany. Environmental Politics, 1-20. doi:10.1080/09644016.2021.1892979.

69. Kluskens, N., Vasseur, V., \& Benning, R. (2019). Energy Justice as Part of the Acceptance of Wind Energy: An Analysis of Limburg in The Netherlands. Energies, 12(22), 4382. doi:10.3390/en12224382.

70. Kompetenzzentrum Naturschutz und Energiewende (2019, January 31). Anfrage Nr. 196 zu Flächensicherung und Steuerung der Windenergie. https://www.naturschutz-energiewende.de/wpcontent/uploads/20190626_EBR_196_Gebietskategorien_TE_korr.pdf. Accessed 17 March 2021.

71. Kreis-Anzeiger (2013, July 23). Anlagen sollen 2014 ans Netz gehen; Windpark Erster Spatenstich bei Kefenrod / Vier Windräder werden gebaut / 20 Millionen Kilowatt Strom jährlich. Kreis-Anzeiger.

72. Kreis-Anzeiger (2014, June 12). Tag der offenen Tür im Windpark. Kreis Anzeiger.

73. Kreisbote (2010, December 28). Wirbel ums Windrad. Lokales. kreisbote.de. https://www.kreisbote.de/lokales/starnberg/wirbel-windrad-2584673.html. Accessed 28 June 2021.

74. Krug, M., \& Di Nucci, M. R. (2020). Citizens at the heart of the energy transition in Europe?: Opportunities and challenges for community wind farms in six European countries. Renewable Energy Law Policy Review, 10(9), 9-27.

75. Kunze, S. (2007, October 1). Von weiteren Anlagen ist nichts bekannt. Lausitzer Rundschau Online. https://www.Ir-online.de/lausitz/herzberg/_von-weiteren-anlagen-ist-nichts-bekannt_-35651380.html. Accessed 4 July 2021.

76. Kunze, S. (2012, March 13). Einnahmen aus Windpark für Schulessen. Lausitzer Rundschau Online. https://www.Ir-online.de/lausitz/elsterwerda/einnahmen-aus-windpark-fuer-schulessen33886170.html. Accessed 7 July 2021.

77. Kunze, S. (2014, August 27). In Uebigau gibt es jetzt eine Anlaufstelle für Fragen zum Bürgerwind. Lausitzer Rundschau Online. https://www.Ir-online.de/lausitz/herzberg/in-uebigau-gibt-es-jetzt-eineanlaufstelle-fuer-fragen-zum-buergerwind-37468178.html. Accessed 7 July 2021.

78. Kunze, S. (2017, November 20). Frischer Wind für Projekt: Bürgerwindrad Uebigau. Bürgerveranstaltung. Lausitzer Rundschau Online. https://www.Ironline.de/lausitz/herzberg/buergerveranstaltung-frischer-wind-fuer-projekt-_buergerwindraduebigau_-37908656.html. Accessed 13 December 2021.

79. Kurz, M. (2015, November 10). Aufstellung des vorhabenbezogenen Bebauungsplanes Nr. 76 'Windenergieanlagenpark 'Hammelwarder Moor: Bekanntmachung vom 13. November 2015. Stadt 
Brake. https://www.brake.de/menu-left/rathaus-informationen/oeffentlichebekanntmachungen/archivierte-bekanntmachungen/browse/47/. Accessed 1 July 2021.

80. Kurz, M. (2016). Aufstellung des vorhabenbezogenen Bebauungsplanes Nr. 75 "Windenergieanlagenpark Golzwarder Wurp": Bekanntmachung. Brake.

81. Landtag Brandenburg (2021). Zweites Gesetz zur Änderung des Gesetzes zur Regionalplanung und zur Braunkohlen-und Sanierungsplanung: vom 23. Juni 2021. Gesetz- und Verordnungsblatt für das Land Brandenburg, 32.(19).

82. Lausitzer Rundschau (21.12.11). Erste Interessenten für das Bürger-Windrad in Uebigau. Lausitzer Rundschau Online. https://www.Ir-online.de/lausitz/herzberg/erste-interessenten-fuer-das-buergerwindrad-in-uebigau-33210132.html. Accessed 07.07.21.

83. Lausitzer Rundschau (2016, October 12). Schülerakademie punktet mit Windmesser und Windbeutel. Lausitzer Rundschau Online. https://www.Ir-online.de/lausitz/herzberg/schuelerakademie-punktetmit-windmesser-und-windbeutel-35751904.html. Accessed 7 July 2021.

84. Leer Jørgensen, M., Anker, H. T., \& Lassen, J. (2020). Distributive fairness and local acceptance of wind turbines: The role of compensation schemes. Energy Policy, 138, 111294. doi:10.1016/j.enpol.2020.111294.

85. Leiren, M. D., Aakre, S., Linnerud, K., Julsrud, T. E., Di Nucci, M.-R., \& Krug, M. (2020). Community Acceptance of Wind Energy Developments: Experience from Wind Energy Scarce Regions in Europe. Sustainability, 12(5), 1754. doi:10.3390/su12051754.

86. Lennon, B., Dunphy, N. P., \& Sanvicente, E. (2019). Community acceptability and the energy transition: a citizens' perspective. Energy, Sustainability and Society, 9(1), 1-18. doi:10.1186/s13705-019-0218$z$.

87. Lori, G. (2009, September 3). Bebauungsplan für Windpark Kefenrod: Auch die Gemeinde Kefenrod hat - wenn auch zögerlich - jetzt die gesetzlichen Vorgaben erfüllt. Kreis-Anzeiger. https://www.genios.de/presse-archiv/artikel/KRAN/20090103/bebauungsplan-fuer-windparkkefenro/2010805290001230937200.html. Accessed 13 December 2021.

88. McCauley, D., \& Heffron, R. (2018). Just transition: Integrating climate, energy and environmental justice. Energy Policy, 119, 1-7. doi:10.1016/j.enpol.2018.04.014.

89. McCauley, D., Heffron, R., Stephan, H., \& Jenkins, K. (2013). Advancing energy justice: the triumvirate of tenets and systems thinking. International Energy Law Review, 32(3), 107-110.

90. McCauley, D., Ramasar, V., Heffron, R. J., Sovacool, B. K., Mebratu, D., \& Mundaca, L. (2019). Energy justice in the transition to low carbon energy systems: Exploring key themes in interdisciplinary research. Applied Energy, 233-234, 916-921. doi:10.1016/j.apenergy.2018.10.005.

91. Merkur (2010, December 13). Berg: Genz will ein zweites Windrad bauen. Merkur.de. https://www.merkur.de/lokales/starnberg/genz-will-zweites-windrad-bauen-1045799.html. Accessed 28 June 2021.

92. Merkur (2011, September 21). Windräder bei Berg: Info-Kampagne gegen Protestwelle. Merkur.de. https://www.merkur.de/lokales/starnberg/windraeder-info-kampagne-gegen-protestwelle- 
1414312.html. Accessed 1 July 2021.

93. Merkur (2014, September 1). Auch in Berg wehren sich die Bürger. Merkur.de.

https://www.merkur.de/lokales/muenchen-lk/auch-berg-wehren-sich-buerger-3820534.html. Accessed 1 July 2021.

94. Milchram, C., Märker, C., Schlör, H., Künneke, R., \& van de Kaa, G. (2019). Understanding the role of values in institutional change: the case of the energy transition. Energy, Sustainability and Society, 9(1), 1-14. doi:10.1186/s13705-019-0235-y.

95. Moser, P. (2012). Regionale Erfolgsbeispiele auf dem Weg zu 100\% EE: Sammelband zur Posterausstellung „100\%-EE-Meile“. Kassel.

96. Müller, T. (2020). Steuerung eines bundesweiten Erneuerbaren-Ausbaus im EEG 2021. Stiftung spezial \#EEG2021. Würzburg.

97. Mundaca, L., Busch, H., \& Schwer, S. (2018). 'Successful' low-carbon energy transitions at the community level? An energy justice perspective. Applied Energy, 218, 292-303. doi:10.1016/j.apenergy.2018.02.146.

98. Narr, D., Ehnes, T., \& Schraml, e. (2013). Gemeinde Berg, Landkreis Starnberg. Bebauungsplan Nr. 88 „Wadlhauser Gräben“: Umweltbericht nach $\S$ 2a BauGB. Vorentwurf vom 18.07.2013, geändert am 01.10.2013. Marzling.

99. Neff, A., Donnerstag, C., Raber, W., Dieme, M., Scheffer, R., Stubenrauch, H., et al. (2013). Windenergie und Kommunen: Leitfaden für die kommunale Praxis. Mainz.

100. Neukirch, M. (2016). Protests against German electricity grid extension as a new social movement? A journey into the areas of conflict. Energy, Sustainability and Society, 6(1). doi:10.1186/s13705-0160069-9.

101. NWZ (2015, April 30). Wind von vorn für Investoren. NWZonline.de. https://www.nwzonline.de/wesermarsch/wirtschaft/wind-von-vorn-fuerinvestoren_a_27,0,1028432963.html.

102. NWZ (2015, November 12). Pläne für Windpark liegen aus. NWZonline.de. https://www.nwzonline.de/wesermarsch/wirtschaft/plaene-fuer-windpark-liegenaus_a_6,0,185330683.html. Accessed 12 November 2015.

103. NWZ (2015, December 7). Windpark ist Thema. NWZonline. https://www.nwzonline.de/wesermarsch/wirtschaft/windpark-ist-thema_a_6,0,1128230651.html. Accessed 6 July 2021.

104. Ohlhorst, D. (2018). Akteursvielfalt und Bürgerbeteiligung im Kontext der Energiewende in Deutschland: das EEG und seine Reform. In L. Holstenkamp \& J. Radtke (Eds.), Handbuch Energiewende und Partizipation (pp. 101-124, Handbuch). Wiesbaden: Springer VS.

105. Ohlhorst, D., Tews, K., \& Schreurs, M. (2013). Energiewende als Herausforderung der Koordination im Mehrebenensystem. Zeitschrift für Technikfolgenabschätzung in Theorie und Praxis, 22(2), 48-55.

106. Ostrom, E. (2000). Collective Action and the Evolution of Social Norms. The Journal of Economic Perspectives, 14(3), 137-158. 
107. Ostrom, E. (2005). Understanding institutional diversity. Princeton, NJ: Princeton University Press.

108. Ostrom, E. (2011). Background on the Institutional Analysis and Development Framework. Policy Studies Journal, 39(1), 7-27. doi:10.1111/j.1541-0072.2010.00394.x.

109. OVAG Oberhessische Versorgungsbetriebe AG (n.d.). Windkraftanlagen der OVAG: Windpark Kefenrod. https://www.ovag.de/ueber-uns/erneuerbare-energien/windkraft/anlagen.html. Accessed 2 July 2021.

110. Potengowski, O. (2013). »Windräder und Naturschutz vereinbar«: Umweltausschuss des Kreistags besichtigt Windenergiestandorte. Wetterauer Zeitung, (107), 34.

111. Potengowski, O. (2013, March 28). Rudolf Kessler will Kefenrods Bürgermeister werden; Christdemokraten nominieren den 54-jährigen EDV-Berater und Ersten Beigeordneten auf ihrer jüngsten Mitgliederversammlung einstimmig. Kreis-Anzeiger.

112. Potengowski, O. (2013, May 2). Standorte für Windkraftanlagen besichtigt; Kreistags-Ausschuss nimmt mögliche Flächen vor Ort in Augenschein - Danach positive Reaktionen zu vernehmen. KreisAnzeiger.

113. Quentin, J. (2019). Hemmnisse beim Ausbau der Windenergie in Deutschland: Ergebnisse Branchenumfrage zu Klagen und anderen Hemmnissen für WEA (Q2/2019). Berlin.

114. Radtke, J., Holstenkamp, L., Barnes, J., \& Renn, O. (2018). Concepts, Formats, and Methods of Participation: Theory and Practice. In L. Holstenkamp \& J. Radtke (Eds.), Handbuch Energiewende und Partizipation (21-42, Handbuch). Wiesbaden: Springer VS.

115. Regionaldatenbank Deutschland (2021). 12411-01-01-5 Bevölkerung nach Geschlecht - Stichtag 31.12. - regionale Tiefe: Gemeinden: Gemeindecodes: 09188113 (Berg, Starnberg), 0346102 (Brake, Unterweser), 06440013 (Kefenrod, Hessen), 12062500 (Uebigau-Wahrenbrück). Statistische Ämter des Bundes und der Länder.

116. Regionaldatenbank Deutschland (2021). 12411-07-01-5: Durchschnittsalter der Bevölkerung Stichtag 31.12. - regionale Tiefe: Gemeinden“: Gemeindecodes: 09188113 (Berg, Starnberg), 0346102 (Brake, Unterweser), 06440013 (Kefenrod, Hessen), 12062500 (Uebigau-Wahrenbrück). Statistische Ämter des Bundes und der Länder.

117. Regionaldatenbank Deutschland (2021). 33111-01-02-5: Bodenfläche nach Art der tatsächlichen Nutzung - Stichtag 31.12 - regionale Tiefe: Gemeinden (ab 2016): Gemeindecodes: 09188113 (Berg, Starnberg), 0346102 (Brake, Unterweser), 06440013 (Kefenrod, Hessen), 12062500 (UebigauWahrenbrück) (Uebigau-Wahrenbrück). Statistische Ämter des Bundes und der Länder.

118. Schiefke, R. (2014). 13.03.2014, 18:00 Uhr, Bau-, Planungs-, Energie- und Umweltausschuss, Rathaus, Ratssaal.: Tagesordnung. Bekanntmachung vom 05. März 2014.

119. Schlager, E., \& Cox, M. (2017). The IAD Framework and the SES Framework: An Introduction and Assessment of the Ostrom Workshop Frameworks. In C. M. Weible \& P. A. Sabatier (Eds.), Theories of the Policy Process (215-252). New York, NY / Oxon: Routledge; Westview Press.

120. Schlüter, U. (2016, April 19). Windpark-Planungen gehen in die nächste Runde. NWZonline.de. https://www.nwzonline.de/wesermarsch/wirtschaft/windpark-planungen-gehen-in-die-naechste- 
runde_a_6,1,2414567736.html. Accessed 1 July 2021.

121. Schlüter, U. (2016, May 14). Geld aus Stiftung für Vereine. NWZonline. https://www.nwzonline.de/wesermarsch/politik/geld-aus-stiftung-fuervereine_a_31,0,261217825.html. Accessed 5 July 2021.

122. Schlüter, U. (2016, June 18). Planungen für Windpark reifen. Stadtrat. NWZonline. https://www.nwzonline.de/wesermarsch/politik/planungen-fuer-windparkreifen_a_31,0,1497179340.html. Accessed 6 July 2021.

123. Schlüter, U. (2017, November 11). Gerichte stoppen gleich zwei Windparks. NWZonline. https://www.nwzonline.de/wesermarsch/wirtschaft/brake-barghorn-energie-gerichte-stoppen-gleichzwei-windparks_a_32,1,1384913947.html. Accessed 13 December 2021.

124. Schlüter, U. (2018, October 13). Windpark liefert Strom für 7800 Haushalte. Energie. NWZonline.de. https://www.nwzonline.de/wesermarsch/wirtschaft/brake-energie-windpark-liefertstrom_a_50,2,3288807793.html. Accessed 13 December 2021.

125. Schlüter, U. (2020, November 6). Wenn der Lärm die Idylle stört. Windenergie in Brake. NWZonline. https://www.nwzonline.de/plus-wesermarsch/brake-windenergie-in-brake-wenn-der-laerm-die-idyllestoert_a_50,10,3153455353.html. Accessed 5 July 2021.

126. Schmalz, I. M. (2019). Akzeptanz von Großprojekten: Eine Betrachtung von Konflikten, Kosten- und Nutzenaspekten und Kommunikation (Politik gestalten - Kommunikation, Deliberation und Partizipation bei politisch relevanten Projekten). Wiesbaden: Springer Fachmedien Wiesbaden.

127. Schreurs, M., \& Ohlhorst, D. (2015). NIMBY and YIMBY: Movements For and Against Renewable Energie in Germany and the United States. In C. Hager \& M. A. Haddad (Eds.), Nimby Is Beautiful: Cases of Local Activism and Environmental Innovation around the World (1 ${ }^{\text {st }}$ ed., pp. 60-86). New York, NY: s.n.

128. Schuster, W. (2013). Politikgestaltung als lernender Prozess: „Stuttgart 21“ aus einer politischen Sicht. In F. Brettschneider \& W. Schuster (Eds.), Stuttgart 21: Ein Großprojekt zwischen Protest und Akzeptanz (pp. 329-343). Wiesbaden: Springer VS.

129. Schwerdtfeger, T. (2015, April 16). Noch herrscht Ruhe vor dem Sturm. Windpark. NWZonline. https://www.nwzonline.de/wesermarsch/wirtschaft/noch-herrscht-ruhe-vor-demsturm_a_26,0,1734586210.html. Accessed 2 July 2021.

130. Schwerdtfeger, T. (2015, September 15). Jetzt wird es ernst für den Windpark. NWZonline.de. https://www.nwzonline.de/brake/jetzt-wird-es-ernst-fuer-den-windpark_a_30,1,920305103.html. Accessed 6 July 2021.

131. Sing, R. (2014). Informationsveranstaltung Bürgerwind Berg GmbH \& Co. KG i.G.: Projekthistorie, Planungsstand, Wirtschaftlichkeit, Beteiligung. 0. 0.

132. Sovacool, B. K., Burke, M., Baker, L., Kotikalapudi, C. K., \& Wlokas, H. (2017). New frontiers and conceptual frameworks for energy justice. Energy Policy, 105, 677-691. doi:10.1016/j.enpol.2017.03.005. 
133. Sovacool, B. K., \& Dworkin, M. H. (2015). Energy justice: Conceptual insights and practical applications. Applied Energy, 142(March), 435-444. doi:10.1016/j.apenergy.2015.01.002.

134. Statistische Ämter des Bundes und der Länder, Gemeinsames Statistikportal (2016-2021). Volkswirtschaftliche Gesamtrechnungen der Länder: Einkommen der privaten Haushalte in den kreisfreien Städten und Landkreisen der Bundesrepublik Deutschland 1995 bis 2018 Reihe 2, Kreisergebnisse Band 3. Tabellenteile 2.4 - Verfügbares Einkommen der privaten Haushalte einschl. der privaten Organisationen ohne Erwerbszweck je Einwohner.

135. Striegnitz, G. (2011, May 24). Erhalt der Landschaft im Vordergrund; Keine Gemeinsamkeit beim interkommunalen Windpark - Kefenrod und Gedern treiben Projekt aber getrennt voran. KreisAnzeiger.

136. Taubert, C. (n.d.). Wo Windkraft in der Lausitz noch wachsen darf. Regionale Planungsgemeinschaft Lausitz-Spreewald.

137. Tomerius, S. (2017). Kommunale Verantwortlichkeiten und Ansatzpunkte im Rahmen der Energiewende: Analyse des nationalen kommunalrechtlichen Rechtsrahmens. im Vorhaben EnGovernance (Teilbericht - Arbeitspaket 1). Berlin.

138. UKA Umweltgerechte Kraftanlagen GmbH \& Co. KG. Windpark Uebigau: Windenergiepark Uebigau. https://www.buergerwind-uebigau.de/. Accessed 3 July 2021.

139. UKA Umweltgerechte Kraftanlagen GmbH \& Co. KG (2018). DKB-Bürgersparen in Uebigau erfolgreich: Zeichnung erfolgreich beendet: Nach drei Wochen bereits 1.000.000 Euro ausgeschöpft. Pressemeldung. Uebigau.

140. Unger, F. (2012, August 12). „Berg schützt die Nachbargemeinden“. Merkur.de. https://www.merkur.de/lokales/muenchen-lk/berg-schuetzt-nachbargemeinden-1359052.html. Accessed 5 July 2021.

141. Verein zum Schutz der Wadlhauser Gräben (n.d.). Der Verein. http://wadlhausergraeben.info/verein. Accessed 1 July 2021.

142. Wagner, J. (2011, March 19). Der Einstieg in den Ausstieg wird vor Ort geregelt: Zur Kommunalwahl am 27. März: Was sagen die Programme der Wetterauer Parteien über die Energiewende aus? Wetterauer Zeitung, p. 55.

143. Wegner, N., \& Sailer, F. (2018). Übergreifende Entwicklungslinien und aktuelle Herausforderungen im Recht der Windenergie: Der Windenergieausbau zwischen Planung, Genehmigung und Förderung. Windenergierecht - Planung, Genehmigung und Förderung im Föderalismus" (WindPlan - FKZ 03MAP307) (Würzburger Studien zum Umweltenergierecht). Würzburg.

144. Wenke, B. (2015, August 18). 3800 strikte Windkraft-Gegner. Weser-Kurier.de. https://www.weserkurier.de/bremen/3800-strikte-windkraft-gegner-doc7e3aa21nvptrf5tp16h. Accessed 2 July 2021.

145. Wenzel, F.-T. (2020, September 7). EEG-Novelle: MVV-Chef Müller sieht in Gesetzentwurf "großen Schritt nach vorne". RND RedaktionsNetzwerk Deutschland. https://www.rnd.de/wirtschaft/runderneuerung-des-eeg-windkraft-soll-deutlich-vorangetrieben- 
werden-bei-solarenergie-besteht-weiter-handlungsbedarf-

NRQOVUHAHVD4NDDUXHAHH3W2GA.html. Accessed 25 October 2021.

146. Willeke, D. (2016). Energiegeladene LOUISE - 7. Erneuerbare-Energien-Messe am 03. Juli 2016: Dampf erleben - E-Mobil testen - Erneuerbar sanieren.

https://www.klima.uewa.de/aktuelles/pressemitteilungen/17-energiegeladene-louise-7-erneuerbareenergien-messe-am-03-juli-2016-dampf-erleben-e-mobil-testen-erneuerbar-sanieren.html. Accessed 7 July 2021.

147. Willeke, D. (2016). Meine Heimat wenn ich groß bin - Auszeichnung der Preisträger des 7. Malwettbewerbs in der Kurstadtregion. https://www.klima.uewa.de/aktuelles/pressemitteilungen/20meine-heimat-wenn-ich-gross-bin-auszeichnung-der-preistraeger-des-7-malwettbewerbs-in-derkurstadtregion.html. Accessed 13 December 2021.

148. Willeke, D. (2017). Bürgerwind mit Rückenwind - Mit dem Windpark Uebigau finanziell gewinnen. https://www.klima.uewa.de/aktuelles/pressemitteilungen/103-buergerwind-mit-rueckenwind-mitdem-windpark-uebigau-finanziell-gewinnen.html. Accessed 7 July 2021.

149. Willeke, D. (2017). Projektaufruf Schutz Sicherheit Wissen - Ideen- und Kooperationsbörse zur Klimafolgenanpassung. https://www.klima.uewa.de/aktuelles/pressemitteilungen/45-projektaufrufschutz-sicherheit-wissen-ideen-und-kooperationsboerse-zur-klimafolgenanpassung.html. Accessed 7 July 2021.

150. Wüstemann, H., Bonn, A., Albert, C., Bertram, C., Biber-Freudenberger, L., Dehnhardt, A., et al. (2017). Synergies and trade-offs between nature conservation and climate policy: Insights from the "Natural Capital Germany - TEEB DE" study. Ecosystem Services, 24(April 2017), 187-199. doi:10.1016/j.ecoser.2017.02.008.

151. Wüstenhagen, R., Wolsink, M., \& Bürer, M. J. (2007). Social acceptance of renewable energy innovation: An introduction to the concept. Energy Policy, 35(5), 2683-2691. doi:10.1016/j.enpol.2006.12.001.

152. Zahn, G. (2005, August 25). Gegen Windkraft in der Region Sturm der Empörung. Lausitzer Rundschau Online. https://www.Ir-online.de/lausitz/herzberg/gegen-windkraft-in-der-region-sturmder-empoerung-35191060.html. Accessed 4 July 2021.

153. Zuber, F., \& Krumm, A. (2020). Akzeptanz und lokale Teilhabe in der Energiewende: Handlungsempfehlungen für eine umfassende Akzeptanzpolitik. Impuls. Berlin.

\section{Figures}




\begin{tabular}{|c|c|c|c|}
\hline THEORY & ASPECT & CONCEPT & INDICATOR \\
\hline \multirow{9}{*}{$\begin{array}{l}\text { ENERGY } \\
\text { JUSTICE }\end{array}$} & \multirow{7}{*}{$\begin{array}{l}\text { PROCEDURAL } \\
\text { JUSTICE }\end{array}$} & DECISION - MAKING & BIASES \\
\hline & & \multirow{3}{*}{ CONSULTATION PROCESS } & ABILITY TO BE HEARD \\
\hline & & & INSTITUTIONAL REPRESENTATION \\
\hline & & & ACCESS TO CONSULTATION \\
\hline & & \multirow[t]{3}{*}{ INFORMATION SHARING } & INFORMATION DISCLOSURE \\
\hline & & & OBJECTIVITY \& ADEQUACY \& TIMELINESS \\
\hline & & & MOBILISATION OF LOCAL KNOWLEDGE \\
\hline & \multirow{2}{*}{$\begin{array}{l}\text { DISTRIBUTIVE } \\
\text { JUSTICE }\end{array}$} & \multirow[t]{2}{*}{ OUTCOMES } & ALLOCATION OF COSTS \\
\hline & & & ALLOCATION OF BENEFITS \\
\hline
\end{tabular}

Figure 1

Analytical Framework for Energy Justice [97] 